\title{
Klatno se i dalje njiše. Institucionalna religioznost riječkih studenata
}

\author{
Željko Boneta \\ Učiteljski fakultet u Rijeci, Rijeka, Hrvatska \\ e-mail: zboneta@uniri.hr
}

\begin{abstract}
SAŽETAK Tekst analizira institucionalnu religioznost riječkih studenata te problematizira tvrdnju da je religioznost mladih u Hrvatskoj stabilna i da postaje sve sličnija religioznosti „odraslih“. Autor se u analizi oslanja na dostupne podatke nacionalnih IDIZ-ovih istraživanja te na istraživanje provedeno u prvoj polovici 2015. godine na uzorku studenata osam sastavnica riječkog sveučilišta $(N=635)$. Nacionalna istraživanja mladih provedena u posljednjih šest godina ukazuju na stabilizaciju aktualne religioznosti u dimenziji religijskih vjerovanja. Istodobno, značajno je smanjena religijska samoidentifikacija i participacija u religijskim obredima, pa su mladi, a posebno studenti u okviru te dobne skupine, opet uvjerljivo najmanje religiozna kategorija $\mathrm{u}$ hrvatskom društvu.
\end{abstract}

Istraživanje na uzorku riječkih studenata pokazalo je izrazito većinsku proširenost tradicionalne religioznosti, no ipak manju od rezultata na nacionalnoj razini. Riječki su studenti u obrednom religijskom ponašanju izjednačeni, a u indikatorima religijskog vjerovanja i religijske samoidentifikacije značajno manje religiozni od nacionalnih prosjeka mladih i studenata. Statistička je obrada pokazala da su sociodemografska obilježja ispitanika (spol, veličina naselja, obrazovanje roditelja i dio Hrvatske iz kojeg potječu) povezana s indikatorima aktualne religioznosti u skladu s kontekstualnom teorijom sekularizacije. Nekonzistentnost identifikacije, ponašanja i vjerovanja među studentima sugerira da je na djelu „distancirana crkvenost“, koja uključuje vrlo sporadičnu vezu većine ispitanika s crkvenom organizacijom, a kod nezanemarivog dijela ta je veza, barem trenutno, u prekidu. Postojeća nestabilnost institucionalne religioznosti mladih i studenata može se objasniti tezom o njihanju klatna koje se nakon vrhunca na religijskom polu početkom ovog stoljeća vraća prema centru, a po nekim indikatorima opet ide prema nereligijskom polu.

Ključne riječi: studenti, mladi, crkvena religioznost, tradicionalna religioznost, aktualna religioznost. 


\section{Uvod}

Vezanost ljudi za religiju i crkvu jedna je od najsustavnije istraživanih tema hrvatske sociologije. Opći je zaključak istraživanja da je hrvatsko društvo posljednjih četrdesetak godina prošlo put od društva u kojem, uslijed procesa sekularizacije, dolazi do „problematizacije prisutnosti religije i crkve na grupnoj i osobnoj razini društvenog života“ (Vrcan, 1980.:340-341) do društva koje, u europskim razmjerima, bilježi visoku razinu religioznosti (Črpić i Zrinščak, 2010.; Nikodem i Zrinščak, 2012.). Analitičari globalnih religijskih kretanja uzimaju podatke iz Hrvatske i nekolicine bivših realsocijalističkih zemalja (npr. Poljska, Rumunjska) kao argument rasta institucionalne religioznosti u dijelu Europe. Drugi, oprečan trend smanjenja religioznosti nalaze na njenom zapadu, ali i u dijelu bivših socijalističkih zemalja (istočni dio Njemačke, Češka i Estonija). Neupitno je da je urušavanjem socijalističkog poretka religija preko noći dobila novi tretman u hrvatskom društvu, što je popraćeno iznimnim rastom vezanosti ljudi uz religiju i crkvu. No u generalizacijama na razini zemalja valja biti iznimno oprezan jer se time zanemaruju lokalne i regionalne razlike koje postoje unutar neke zemlje (Boneta i Banovac, 2007.).

Trend revitalizacije religije umnožio je broj kritičara sekularizacijske paradigme, pa i doveo do toga da se negdašnje njene perjanice odreknu vlastita doprinosa i svoj prethodni rad proglase pogrešnim (Berger, 2008.), jer stara paradigma ne može objasniti novonastale promjene. Pickel (2009.) pak smatra da je sekularizacijska paradigma još uvijek operabilna, ali kao kontekstualizirana teorija sekularizacije, koja uz modernizacijske promjene uvažava i kulturne specifičnosti pojedine zemlje. U tom je duhu Bruceovo objašnjenje porasta religioznosti kao kulturne obrane, u kojem religijski identitet djeluje u sinergiji s nacionalnim/lokalnim/etničkim identitetom (Bruce, 2011.).

Na temelju istraživanja provedenih u Institutu za društvena istraživanja u Zagrebu (IDIS/IDIZ) možemo rekonstruirati što se s institucionalnom religioznošću zbivalo u hrvatskom društvu u proteklih četrdesetak godina te gdje su u svemu tome mladi ${ }^{1}$. Dijagnosticirajući religijsku situaciju sedamdesetih godina dvadesetog stoljeća na uzorku ispitanika iz zagrebačke regije, Vrcan navodi dvadeset značajki vezanosti ljudi uz religiju i crkvu, od kojih ćemo izdvojiti najzanimljivije: usprkos „sistemskom favoriziranju nereligioznosti i ateizma" na istraživanom području postoji izrazito većinska tradicionalna religioznost, koja se „samo jednim dijelom reproducira kao aktualna vezanost“; religijska je samoidentifikacija većinska, a deklarirani ateisti manjinska pojava; vjernici nisu homogena, nego heterogena skupina, unutar koje su vidljive podskupine različitih razina vezanosti; aktualna je vezanost karakterističnija za ruralne, a manje za urbane prostore; prisutan je trend širenja religijske ravnodušnosti,

$\mathbf{1}$ Specifičnost pozicije mladih u društvu posljedica su: procesa strukturnih i kulturnih promjena koje otežavaju i odgađaju radno, financijsko, stambeno i obiteljsko osamostaljenje, procesa individualizacije, kulturne pluralizacije, traganja za osobnim i kolektivnim identitetom, distanciranja od utjecaja roditelja, težnje za autonomijom u oblikovanju vlastitih stavova i vrijednosti, sklonosti novome i eksperimentiranju, kritičkom odnosu spram hijerarhije i tradicije itd. Navedeni procesi naglašenije utječu upravo na poziciju studentske populacije. 
vjerničke selekcije vjerovanja i erozije religijskog ponašanja (Vrcan, 1980.:339). U istom istraživanju mladi (ispitanici do 24 godine života) u većini indikatora iskazuju najmanju tradicionalnu i aktualnu religioznost. Marinović (1988.), interpretirajući podatke nacionalnog istraživanja provedenog 1985. godine, iznosi sljedeće značajke religioznosti mladih: tri četvrtine konfesionalno se identificira; trećina se religiozno identificira, a petina redovito participira u misama. Dakle mladi su sredinom osamdesetih bili većinski tradicionalno religiozni, ali se ta religioznost vrlo malo reproducira u aktualnu vezanost vidljivu u religijskoj samoidentifikaciji i obrednoj praksi. Drugim riječima, značajan dio mladih udaljio se u svakodnevnom iskustvu od religije i crkve. Marinović Jerolimov (1993.) na temelju istraživanja provedenih 1972. i 1982. godine, a na uzorku građana grada Zagreba, naglašava da se mladi najmanje svrstavaju u religiozne, a najviše u nereligiozne od svih dobnih skupina. Sredinom osamdesetih zaustavlja se trend opadanja te počinje trend porasta religioznosti, naročito među mladima, pa se oni, zaključuje autorica, sve manje razlikuju od ostalih dobnih skupina.

U tekstu objavljenom početkom novog milenija Vrcan (2001.) navodi da se u proteklih petnaestak godina dogodila retradicionalizacija hrvatskog društva; da je ono, nasuprot europskog trenda konfesionalne pluralizacije (Giordan, 2010.), postalo monokonfesionalno (katoličko); da religija postaje relevantnom javnom (društvenom, političkom, obrazovnom) činjenicom; da se revitalizira institucionalna religioznost; da se religija nastoji pozicionirati kao „nadsvođujući sistemski i kulturni agregat“; da na mjesto sistemskog favoriziranja ateizma i nereligioznosti dolazi sistemsko favoriziranje teizma i religioznosti; da i dalje religioznost opada s povećanjem veličine naselja, ali da su razlike između najvećih gradova (više od 100.000 stanovnika) i gradova srednje veličine (od 10.000 do 100.000) sve manje te da je religijska socijalizacija uključena u formalnu obrazovnu socijalizaciju (Vrcan, 2001.). Istraživanja otkrivaju da nova slika vezanosti ljudi uz religiju i crkvu uključuje: visoku razinu vjerovanja i samoidentifikacije te masovnu, ali ipak znatno manju aktualnu religioznost. Črpić i Zrinščak (2010.) analizirajući rezultate Europskog istraživanja vrijednosti (EVS) iz 2008. godine nalaze da u Hrvatskoj postoji visoka i stabilna religioznost ${ }^{2}$. Njene značajke 2008. godine jesu izrazito većinska proširenost konfesionalne $(84,3 \%)$ i religijske samoidentifikacije $(79,0 \%)$ te vjerovanja u postojanje Boga (87\%). Participacija u crkvenim obredima također je relativno visoka $(26,4 \% \text { tjedno, a 16,2\% mjesečno })^{3}$, ali ipak znatno manja od pokazatelja iz 1999. godine. Autori primjećuju da je religioznost u prethodnih deset godina uglavnom stabilna, s blagim trendom smanjenja konfesionalnosti i participacije. Črpić i Zrinščak zaključuju: da je Hrvatska zemlja nižeg stupnja sekularizacije od europskog prosjeka; da je religioznost nekonzistentna; da se uočava trend profiliranja dviju skupina - vjerničke i nevjerničke te da je Crkva i dalje „najširi simboličko-identifikacijski okvir" u hrvatskom društvu. Nikodem je suglasan s Črpićem i Zrinščakom da je religioznost u Hrvatskoj stabilna, ali domeće pitanje hoće li ona takva i ostati u „društvenim uvjetima nestabilne dinamičnosti“ (Nikodem, 2011.:26).

2 Sociolozi su suglasni da je crkvena religioznosti dominantni oblik religioznosti u Hrvatskoj (Vrcan, 2001.; Črpić i Zrinščak, 2010.; Nikodem, 2011.; Nikodem i Zrinščak, 2012.).

3 Slični su rezultati dobiveni i u istraživanju „Modernizacija i identitet hrvatskog društva: sociokulturne integracije i razvoj“ provedenom dvije godine kasnije na nacionalnom uzorku (Nikodem, 2011.). 
U prikazu veza sociodemografskih karakteristika i religioznosti nalazimo razlike u naglascima dvaju istraživanja. Te su razlike posljedica toga što su Črpić i Zrinščak orijentirani ka analizi trendova između dvaju provedenih istraživanja (1999. i 2008. godine), a Nikodem se fokusira na prikaz strukture religioznosti u recentnom istraŽivanju. Črpić i Zrinščak (2010.) naglašavaju da se konfesionalna i religijska identifikacija među mladim ispitanicima povećava, za razliku od starijih dobnih skupina gdje dolazi do smanjenja. Nikodem pak uočava da su mladi skloniji smjestiti se u kategoriju „religiozni na svoj načina“ te da su se skloniji identificirati kao agnostici i ateisti. Črpić i Zrinščak naglašavaju da je crkvena participacija mladih stabilna, dok među starijim generacijama ona opada. Nikodem nalazi da su mladi neredovitiji sudionici u crkvenim obredima od starijih.

Zadnje nacionalno istraživanje mladih u okviru kojeg je bila zasebna dionica o religioznosti provedeno je 1999. godine (Radin i sur., 2002.). Interpretirajući rezultate tog istraživanja Marinović Jerolimov (2002.) primjećuje da nereligiozna identifikacija među mladima u dvama analiziranim desetljećima najviše oscilira. Analizirajući trendove promjena religioznosti mladih u Hrvatskoj na temelju triju IDIS-ovih istraŽivanja (1986., 1999. i 2004.) Marinović Jerolimov i Jokić (2010.) uočavaju drastičnu revitalizaciju religioznosti između prvog i drugog istraživanja, a nakon toga slijedi razdoblje stabilizacije. Indikatori revitalizacije jesu povećanja religiozne identifikacije i, iako u znatno manjoj mjeri, religijske participacije. Udio redovitih tjednih praktikanata udvostručio se, dok se udio apstinenata prepolovio. U obama indikatorima najmlađa dobna skupina (15 - 19 godina) pokazuje se kao najreligioznija, više se od ostalih deklarira uvjerenim vjernicima i najredovitiji su u crkvenoj participaciji, što je povezano s uvođenjem vjeronauka u škole. Nakon završetka srednjeg školovanja participacija slabi, a identifikacija se smanjuje. ${ }^{4}$ Autori zaključuju da je na temelju navedenih indikatora utemeljeno pretpostaviti da religioznost mladih nije značajno različita od religioznosti odraslih.

Nakon tog provedena su tri nacionalna istraživanja mladih (Ilišin i Radin, 2007.; Ilišin i sur., 2013.; Ilišin i Spajić Vrkaš, 2015.) te jedno studenata (Ilišin, 2014.), u kojima je religioznost mjerena $s$ manjim brojem indikatora aktualne religioznosti. ${ }^{5}$ Recentna istraživanja pokazuju da aktualna religioznost mladih i dalje značajno oscilira. Klatno se nastavilo njihati i sada se kreće prema drugoj strani u odnosu na poziciju početkom stoljeća, jer je među mladima zabilježen značajan trend smanjenja nekih

4 Sličnu tendenciju na uzorku američke mladeži nalazi i Arnett (2015.). Statistički značajna veza roditeljske i dječje religioznosti postoji u razdoblju adolescencije $(13-17$ g.), ali potpuno nestaje nakon toga u razdoblju koje on naziva dvojbenim terminom nastajuća odraslost (engl. emerging adulthood).

5 Riječ je o istraživanjima „Mladi i europski integracijski procesi“ iz 2004. godine (Ilišin i Radin, 2007.), „Percepcije i stavovi mladih Hrvatske prema stvarnosti koja se mijenja“, (Ilišin i sur., 2013.) iz 2012. godine, „Potrebe, problemi i potencijali mladih u RH“ (Ilišin i Spajić Vrkaš, 2015.) iz 2014. godine i „Sociološki portret hrvatskih studenata“ iz 2010. godine (Ilišin, 2014). Početno stanje religioznosti mladih u Hrvatskoj utvrđeno je istraživanjem „Položaj, svijest i ponašanje mlade generacije Jugoslavije“ iz 1986. godine (Marinović, 1988.; Goja 2000.), a velike su promjene zabilježene u istraživanju „Vrijednosni sustav mladih i društvene promjene u Hrvatskoj“ iz 1999. godine (Radin i sur., 2002.). 
dimenzija religioznosti. Koliko se riječki studenti uklapaju u opću sliku religioznosti u Hrvatskoj, koliko u sliku religioznosti mladih, a koliko u sliku religioznosti hrvatskih studenata? U kojoj mjeri religioznost riječkih studenata obilježava unutarnja diskrepancija između tradicionalne i aktualne religioznosti?

\section{Metodologija i uzorak}

Ciljevi ovog rada jesu: (1) prikazati tradicionalnu i aktualnu religioznosti anketiranih studenata te usporediti rezultate s religioznošću na nacionalnoj razini (građana, mladih i studenata); (2) utvrditi vezu između indikatora tradicionalne i aktualne religioznosti te (3) utvrditi vezu sociodemografskih karakteristika i religioznosti.

U istraživanju se pošlo od sljedećih hipoteza:

H1 Budući da je tradicionalna religioznost u Hrvatskoj konstantno prisutna kao većinska pojava, njeni će pokazatelji (konfesionalna pripadnost, krštenje, odgoj u vjeri i pohađanje vjeronauka) unutar studentske populacije biti većinski prošireni.

H2 Indikatori aktualne vezanosti (religijska vjerovanja, religijsko ponašanje i religijska samoidentifikacija) bit će manje prošireni od indikatora tradicionalne vezanosti.

H3 Postoje razlike u aktualnoj religioznosti, koje su povezane sa sociodemografskim karakteristikama studenata (spolom, veličinom naselja u kojima su odrasli, obrazovanjem roditelja, dijelom Hrvatske iz kojeg dolaze).

H4 Studenti će u svim indikatorima aktualne religioznosti biti manje religiozni od prosjeka mladih i prosjeka opće populacije.

Terensko anketiranje provedeno je od siječnja do ožujka 2015. godine na prigodnom uzorku $(\mathrm{N}=635)$ studenata riječkog sveučilišta. U anketiranju su sudjelovali studenti osam sastavnica riječkog sveučilišta. ${ }^{6} \mathrm{Za}$ ovu su prigodu rezultati obrađeni u statističkom paketu SPSS 21 na razini univarijantne i bivarijantne analize.

U uzorku (tablica 1.) je više studentica nego studenata, s obzirom na godinu studija prevladavaju brucoši, a trećina je studenata na završnim godinama studija. Najviše je studenata odraslo u manjim mjestima (od 1.000 do 10.000 stanovnika), a podjednak je udio ispitanika iz preostalih triju veličina naselja. Analiza regionalne zastupljenosti otkriva da gotovo dvije trećine ispitanika dolazi iz dviju susjednih županija: Primorsko-goranske i Istarske, petina je iz županija u središnjoj i sjeverozapadnoj Hrvatskoj, desetina iz jugoistočne, a vrlo je mali udio ispitanika iz sjeveroistočne Hrvatske. U daljnjoj statističkoj obradi ispitanici su klasificirani u dvije kategorije bitne za razumijevanje društvenog konteksta u kojem su socijalizirani. U prvu kategoriju

6

${ }^{6}$ U istraživanju su sudjelovali studenti sljedećih sastavnica Sveučilišta u Rijeci (UNIRI): Filozofski fakultet (FFRI), Fakultet za menadžment u turizmu i ugostiteljstvu (FTMU), Građevinski fakultet (GRADRI), Pravni fakultet (PRAVRI), Odjel za fiziku (OFRI), Odjel za informatiku (OIRI), Tehnički fakultet (TEHRI) i Učiteljski fakultet (UFRI). Uzorak na svakoj sastavnici nije bio dovoljan da bismo poopćili rezultate na toj razini, pa su fakulteti klasificirani u dva područja: društveno humanističko i prirodoslovno tehničko. Zahvaljujemo se svim kolegama na navedenim sastavnicama koji su pomogli u provedbi anketiranja. 
smješteni su ispitanici iz županija u kojima je devedesetih godina dvadesetog stoljeća bilo izravnih ratnih djelovanja (20,0\%), a u drugu studenti iz županija u kojima nije bilo izravnih ratnih djelovanja $(76,9 \%)$. Osim po ratnim djelovanjima te se kategorije razlikuju još u dvjema važnim značajkama. U ratom zahvaćenim dijelovima Hrvatske prije rata bila je prisutnija dvoetničnost (Hrvati i Srbi), koja je istodobno bila i dvokonfesionalnost (katolici i pravoslavni), dok u drugim dijelovima konfesionalnost nije bila marker etničkih razlika domicilnih skupina. Druga bitna razlika između tih područja u razini je modernizacije (Boneta, 2007.).7

Tablica 1.

Sociodemografske karakteristike ispitanika (\%)

\begin{tabular}{|l|c|l|c|}
\hline SPOL & & GODINA STUDIJA & \\
\hline ŽENSKO & 60,9 & PRVA & 59,2 \\
\hline MUŠKO & 38,4 & DRUGA & 6,3 \\
\hline B.0. & 0,7 & ČETVRTA & 20,6 \\
\hline DOB $(\bar{x})$ & 20,9 & PETA & 13,9 \\
\hline $18-20$ & 56,5 & B.0. & 1,1 \\
\hline $21-23$ & 30,6 & REGIONALNA ZASTUPLJENOST & \\
\hline 24 I VIŠE & 11,8 & ISTRA I PRIMORJE & 61,6 \\
\hline B.0. & 1,1 & SJEVEROZAPADNA HRVATSKA & 21,7 \\
\hline VELIČINA NASELJA ODRASTANJA & & JUGOISTOČNA HRVATSKA & 9,3 \\
\hline DO 1.000 & 20,8 & SJEVEROISTOČNA HRVATSKA & 4,3 \\
\hline $1.001-10.000$ & 37,3 & B.0. & 3,1 \\
\hline 0.001 - 100.000 & 20,8 & OBRAZOVANJE MAJKE & \\
\hline 100.001 I VIŠE & 20,0 & OSNOVNA ŠKOLA & 5,4 \\
\hline B.0. & 1,1 & TROGODIŠNJA SREDNJA ŠKOLA & 8,7 \\
\hline OBRAZOVANJE OCA & & ČETVEROGODIŠNJA SREDNJA ŠKOLA & 47,9 \\
\hline OSNOVNA ŠKOLA & 2,9 & VIŠA ŠKOLA & 14,0 \\
\hline TROGODIŠNJA SREDNJA ŠKOLA & 14,7 & FAKULTET & 22,9 \\
\hline ČETVEROGODIŠNJA SREDNJA ŠKOLA & 42,7 & B.0. & 1,1 \\
\hline VIŠA ŠKOLA & 17,8 & FAKULTET/ODJEL & \\
\hline FAKULTET & 20,6 & FFRI & 12,6 \\
\hline B.0. & 1,3 & FTMU & 9,3 \\
\hline IMOVINSKO STANJE OBITELJI & & GRADRI & 4,3 \\
\hline ZNATNO LOŠIJE OD VEĆINE DRUGIH & 1,6 & OFRI & 3,0 \\
\hline LOŠIJE OD VEĆINE DRUGIH & 6,9 & OIRI & 12,4 \\
\hline ISTO KA0 I DRUGI & 54,3 & PRAVRI & 12,6 \\
\hline BOLJE OD VEĆINE DRUGIH & 30,4 & TEHRI & 0,2 \\
\hline ZNATNO BOLJE OD VEĆINE DRUGIH & 6,5 & UFRI & \\
\hline B.0. & 0,3 & B.0. & \\
\hline & & & \\
\hline
\end{tabular}

7 Valja imati na umu da u uzorku dominiraju studenti iz dviju (uz Zagreb) najrazvijenijih hrvatskih županija. Budući da su vrijednosti i stavovi povezani s razinom modernizacije pojedine regije, treba biti oprezan pri generalizaciji rezultata ovog istraživanja na cjelokupnu populaciju hrvatskih studenata. Da postoje značajne razlike između religioznosti mladih u pojedinim dijelovima Hrvatske upozorila je Marinović Jerolimov (2002.), jer su mladi iz Istre i Primorja 1999. godine bili manje religiozni od prosjeka. 
Očevi i majke ispitanika podjednake su razine obrazovanja, a u objema kategorijama prevladavaju roditelji sa završenom četverogodišnjom srednjom školom. U polovini obitelji postoji homogamni obrazovni bračni obrazac jer oba roditelja imaju istu razinu obrazovanja. Natpolovična većina procjenjuje imovinsku situaciju svoje obitelji prosječnom, a u krajnje kategorije svrstava se iznimno malo ispitanika, pa su one u daljnjoj statističkoj obradi povezane s umjerenijim modalitetom.

\section{Rezultati i rasprava}

Konfesionalna samoidentifikacija temeljni je indikator tradicionalne/konvencionalne religioznosti. Šundalić ju definira „kao neinstitucionalizirano pripadanje određenoj vjerskoj zajednici, a koje dobiva više svjetovna obilježja nego religijska“ (Šundalić, 1995.:915). Najizraženiji oblik „svjetovne upotrebljivosti“ konfesionalnosti u nas je njeno izjednačavanje s nacionalnom pripadnošću, što je naglašenije u onim dijelovima Hrvatske gdje je konfesionalnost ključni marker između etničkih skupina (Šagi Bunić, 1983.). Posebice je ta upotrebljivost bila vidljiva u ratu, kada konfesionalna identifikacija postaje najjednostavnijim čimbenikom kolektivne identitetske mobilizacije. ${ }^{8}$ Stoga je konfesionalnost vrlo nepouzdan indikator religioznosti, iako je neki autori neopravdano koriste kao ključni argument u klasifikaciji religioznosti čak i na razini pojedinih država.

Rezultati svih nacionalnih istraživanja, kao i popis stanovništva iz 2011. godine, otkrivaju gotovo opće proširenu konfesionalnu katoličku identifikaciju u Hrvatskoj. Istraživanja konfesionalnosti mladih ne nalaze velike razlike u odnosu na onu opće populacije. U istraživanju riječkih studenata konfesionalna identifikacija postavljena je kao otvoreno pitanje, kod kojeg ispitanici upisuju svoju vjeroispovijest. Iznenađujući rezultati prikazani su usporedno s rezultatima istraživanja konfesionalnosti mladih u Hrvatskoj iz 2012. godine u tablici 2.

Tablica 2.

Koje ste vjeroispovijesti? (u \%)

\begin{tabular}{|l|c|c|}
\hline & UNIRI & $\begin{array}{c}\text { MLADI HR* } \\
2012 .\end{array}$ \\
\hline KATOLIČKE & 2015. & 88,8 \\
\hline KRŠ́CANSKE & 51,5 & - \\
\hline OSTALE VJEROISPOVIJESTI & 14,5 & 3,1 \\
\hline ATEIST & 3,0 & 3,2 \\
\hline AGNOSTIK & 7,2 & - \\
\hline NEMA VJEROISPOVIJESTI & 2,7 & 3,2 \\
\hline B.0. & - & 1,8 \\
\hline
\end{tabular}

*Izvor: Ilišin i sur. 2013.:158

8 Barth s pravom upozorava da u interpretaciji granica između etničkih skupina nisu ključni „petrificirani kulturni markeri“, u ovom slučaju konfesionalne razlike, već društveni akteri koji ih interpretiraju (Barth, 1997.). 
Rezultati otkrivaju da se nešto više od dvije trećine (68,98\%) ispitanika konfesionalno identificiralo, što je znatno manje od nacionalnog prosjeka mladih iz 2012. godine (Ilišin i sur, 2013.). Katolika je neznatno više od polovine anketiranih, a svaki sedmi ispitanik deklarira se kršćaninom. Udio onih koji se ne svrstavaju ni u jednu konfesiju ne razlikuje se bitno od nacionalnog istraživanja. Intrigantna je činjenica da više od petine ispitanika nije odgovorilo na to pitanje. O kojim je ispitanicima riječ? Može li se neodgovaranje interpretirati kao nepripadanje? Ukoliko bi tome bilo tako, onda se za objašnjenje znatno manjeg udjela konfesionalno identificiranih od nacionalnog prosjeka nameću dvije hipoteze. Prva govori o pročišćavanju konfesionalne identifikacije od onih koji je doživljavaju isključivo svjetovno. Bilo bi to iznimno brzo ostvarenje Nikodemova (2011.) predviđanja da će značaj svjetovnog iskazivanja konfesionalnosti slabiti. Promjenama u društvenom kontekstu, vremenskim odmakom od rata i etničkih napetosti konfesionalno kao ključna razlika spram etnički drugačijih gubi na važnosti. ${ }^{9}$ Druga hipoteza na tragu je dijagnoze riječkog nadbiskupa Devčića, koji smatra da je „vjersko neznanje gorući problem današnjeg svijeta" (Grce, 2016.). Naime za pretpostaviti je, a kasnije ćemo to i provjeriti, da je dio onih koji nisu odgovorili bio povezan s religijom i crkvom tradicionalnim vezama, ali tu vezu ne zna identificirati u kategorijama konfesije. Vjerojatno se ista logika može primijeniti i na one koji su se definirali kršćanima. Drugim riječima, oni koji su se deklarirali kao kršćani, a i dio onih koji nisu odgovorili, ustvari su katolici koji to ne znaju izreći.

Statistička obrada otkriva da su tri sociodemografske varijable povezane s konfesionalnom identifikacijom: spol $(\mathrm{t}=3,84, \mathrm{p}<, 001)$, veličina naselja u kojoj je ispitanik odrastao $(C=, 14 ; \mathrm{p}<, 05)$ i razina obrazovanja majke $(\mathrm{C}=, 17, \mathrm{p}<, 001)$. Žene se više od muškaraca svrstavaju u konfesionalne, dok se muškarci više svrstavaju u nekonfesionalne i češće ne odgovaraju na to pitanje. Udio konfesionalno identificiranih smanjuje se, a nekonfesionalno identificiranih raste porastom veličine naselja. Trend rasta nekonfesionalnosti s rastom obrazovne razine nalazimo kada je u pitanju obrazovanje majke, ali ne i oca, s tim da je udio nekonfesionalnih u dvjema najobrazovanijim kategorijama identičan.

Dodatnim pitanjem provjereno je kojoj vjerskoj zajednici ispitanici pripadaju. Natpolovična većina ispitanika $(55,9 \%)$ tvrdi da nikada nije pripadala nijednoj vjerskoj zajednici (?!), dok petina $(21,7 \%)$ tvrdi da pripada. Vrlo je mali udio onih koji tvrde da su pripadali, ali više ne pripadaju (5,4\%), a opet relativno veliki udio uzorka $(17,0 \%)$ ne odgovara na to pitanje. Čak i među onima koji priznaju pripadanje jedva nešto više od polovine navodi da je njihova vjerska zajednica Rimokatolička crkva, dok ostali navode imena župe, crkvenih redove, vjerskih udruga mladih i sl. Očito je da veliki dio anketiranih nije razumio pitanje, odnosno ne prepoznaju Rimokatoličku crkvu kao vjersku zajednicu. Polovica ispitanika koji su se konfesionalno deklarirali tvrde da nisu nikada pripadali nekoj vjerskoj zajednici, a dodatna petina

9 To što se konfesionalna dimenzija kolektivnog identiteta u dijelu javnosti pasivizira, naravno ne znači da nestaje njen potencijal da u novim okolnostima bude nanovo osnovom kolektivne mobilizacije. 
nije odgovorila na to pitanje $(\mathrm{C}=, 30, \mathrm{p}<, 001)$. Ispitanici iz ratom zahvaćenih krajeva Hrvatske više od onih drugih tvrde da pripadaju vjerskoj zajednici $(\mathrm{t}=-2,03$; $\mathrm{p}$ $<, 05)$.

Prethodni rezultati, koji pokazuju nerazumijevanje pojma vjerske zajednice, potpuno su neočekivani s obzirom na udio ispitanika koji su pohađali školski vjeronauk. Ogromna većina ispitanika u ovom istraživanju bila je uključena u formalnu školsku vjersku obuku. ${ }^{10}$ Preko dvije trećine $(68,0 \%)$ pohađalo je vjeronauk tijekom cijelog školovanja, dodatnih 14,8\% samo tijekom osnovne škole te 7,7\% samo u nižim razredima osnovne škole. Manje od desetine ispitanika $(8,7 \%)$ nije tijekom školovanja bilo uključeno u formalnu školsku vjersku obuku. Rastom dužine pohađanja vjeronauka raste broj onih koji se konfesionalno identificiraju, a opada udio ateista i agnostika (Cramerov $\mathrm{V}=, 24 ; \mathrm{p}<, 001)$. Ipak čudi da se petina (19,7\%) ispitanika koji su bili dvanaest godina na vjeronauku nije nigdje konfesionalno svrstala, a samo četvrtina (26,9\%) tvrdi da pripada nekoj vjerskoj zajednici (Cramerov V = ,17; p < ,001). Dakle očito je da se pohađanjem vjeronauka kod dijela uzorka nije razvio konfesionalni identitet ni svijest o pripadnosti vjerskoj zajednici. Nakon toga nameće se nekoliko pitanja: je li značajan dio polaznika vjeronauka nakon završene srednje škole doživio konverziju? Je li značajan dio polaznika vjeronauka upisao taj predmet zbog pritiska roditelja, prilagodbe dominantnom obrascu sredine i sl., iako se od početka nisu doživljavali pripadnicima vjerske zajednice čiji su vjeronauk pohađali? Ili je riječ o ignorantskom odnosu prema samom predmetu, kao samo jednom u nizu školskih predmeta, koji se sada manifestira u nezainteresiranosti i neznanju? Konačno, jedna bi se hipoteza mogla smjestiti u kontekst Starkove teorije religijskog tržišta o „lijenosti“ vjernika u društvima u kojima postoji monopol jedne konfesije. Uočeni se paradoksi uklapaju u analizu autorice Potočnik, koja govori o površnoj religijskoj socijalizaciji u kojoj su „obrascima ponašanja kao prazni kodovi, a mladi izvode svoje religijske uloge ne pitajući zašto to čine i koji im je cilj“" (Potočnik, 2007.:374). Nakon svega toga nedvojbeno je da se ni pohađanje vjeronauka ne može samostalno uzeti kao uvjerljiv indikator nečije religioznosti.

Iako je je pohađanje vjeronauka gotovo opće prošireno, nalazimo statistički značajne, doduše nejake, ali indikativne veze te varijable s trima sociodemografskim varijablama. Riječ je o vezama sa spolom $(\mathrm{t}=-2,74 ; \mathrm{p}<, 01)$, dijelom Hrvatske iz koje ispitanici dolaze $(\mathrm{t}=-2,15 ; \mathrm{p}<, 05)$ i veličina naselja $(\mathrm{C}=, 11 ; \mathrm{p}=, 01)$. Studenata je dvostruko više nego studentica (12,5\% : 6,2\%) među onima koji su potpuno apstinirali od vjeronauka. Ispitanici iz ratom zahvaćenih krajeva masovnije su i duže pohađali vjeronauk od onih iz drugih dijelova Hrvatske. Porastom veličine naselja povećava se udio onih koji nisu pohađali te istodobno smanjuje udio onih koji su pohađali vjeronauk čitavo školovanje. Pregled preostalih dvaju indikatora tradicio-

10 Ančić i Puhovski (2011.) iznose podatak da 93,6\% djece u Hrvatskoj polazi vjeronauk u osnovnoj školi, a 75,4\% i tijekom srednje škole. Valja naglasiti da u pohađanju vjeronauka u Hrvatskoj postoje znatne regionalne razlike. U ovom su uzorku najzastupljeniji studenti s područja Primorsko goranske i Istarske županije, koje su se po udjelu polaznika vjeronauka nalazili na dnu liste. Njihov je prosjek 78,66\% polaznika u osnovnoj, a 63,42\% u srednjoj školi (Ančić i Puhovski, 2011.). 
nalne religioznosti (tablica 3.) ukazuje na njihovu većinsku prisutnost, ali i značajnu razliku u proširenosti između njih.

Tablica 3.

Jeste li: (u \%)

\begin{tabular}{|l|c|c|c|}
\hline & NE & DA & B.0. \\
\hline KRŠTENI & 10,2 & 87,2 & 2,52 \\
\hline ODGAJANI U VJERI & 30,9 & 65,4 & 3,78 \\
\hline
\end{tabular}

Inicijacija u vjersku zajednicu krštenjem bio je i ostao najprošireniji indikator „religioznosti bez osobne odluke" u nas. Gotovo identičan postotak, devet od deset ispitanika, prošao je inicijaciju u vjersku zajednicu i kasnije pohađao školski vjeronauk. Ogroman postotak krštenih među ispitanicima pokazuje da je inicijacija u vjersku zajednicu dio normalnog ponašanja u anketiranoj populaciji. Istodobno, tolika proširenost krštenja onemogućuje postojanje značajnih statističkih razlika unutar uzorka. Značajno je manje ispitanika odgajano u vjeri nego što je kršteno. Dakle dio ispitanika krsti svoju djecu, ali ih kasnije ne odgaja religiozno. Još veći dio upisuje djecu na školski vjeronauk, iako ih u obitelji ne odgaja u vjeri. Statistički značajna veza između krštenja i odgoja u vjeri naravno postoji $(t=-9,73 ; p<, 001)$, pa je tri četvrtine krštenih $(73,5 \%)$ odgajano u vjeri, ali četvrtina ipak nije. U skupini ispitanika koji nisu kršteni nalazimo nešto veću dosljednost, a konvertitstvo je nešto rjeđe, jer je svaki sedmi (16,4\%) odgajan u vjeri. Zanemariv postotak $(3,8 \%)$ krštenih ispitanika nije polazio vjeronauk u nekom razdoblju školovanja $(\mathrm{C}=, 48 ; \mathrm{p}<, 001)$. No ipak je dio odustajao nakon nižih $(7,8 \%)$, a dio nakon viših (15,0\%) razreda osnovne škole. Zanimljivo je da vjeronauk tijekom školovanja pohađa i gotovo polovina $(46,2 \%)$ ispitanika koji nisu kršteni. I između tih varijabli postoji statistička veza jer se religijska socijalizacija prisutna u obitelji najčešće nastavlja pohađanjem vjeronauka u školi $(C=, 43 ; \mathrm{p}<, 001)$. Četiri petine ispitanika odgajanih u vjeri $(82,4 \%)$ pohađa vjeronauk tijekom cijelog školovanja. No zanimljivije je da tri četvrtine $(76,7 \%)$ onih koji nisu imali religijsku obiteljsku socijalizaciju ipak pohađaju vjeronauk u nekim razdobljima svoga školovanja, a više od polovice to čini tijekom cijelog školovanja. Pohađanja vjeronauka ispitanika koji nisu prošli obred kršćanske inicijacije i koje roditelji nisu odgajali religiozno možemo pripisati favoriziranju religije i religioznosti kao dijela društvene normalnosti. Stoga dio roditelja djecu ne odgaja religiozno, ali ih ipak uključuju u vjeronauk, izbjegavajući na taj način rizik njihove stigmatizacije zbog izdvajanja iz grupe (Ančić i Puhovski, 2011.). Odgoj u vjeri povezan je s razinom obrazovanja majke $(\mathrm{t}=-3,63 ; \mathrm{p}<, 001)$ na način da povećanjem razine obrazovanja pada udio odgajanih u vjeri, a raste udio onih koji to iskustvo nisu imali. Odgoj u vjeri prisutniji je u ratom zahvaćenim krajevima $(\mathrm{t}=-2,55 ; \mathrm{p}<, 01)$, gdje su tako odgajane tri četvrtine, naspram dvije trećine u drugim dijelovima. Možemo zaključiti da su svi indikatori tradicionalne religioznosti povezani s ozračjem u obitelji orijentacije u anketiranoj populaciji većinski prošireni. Tradicionalna religioznost dio je ozračja većine obitelji, uz nevelike, ali indikativne razlike koje su povezane sa spolom, veličinom naselja, obrazovanjem majke i područjem Hrvatske iz kojeg je ispitanik. Navedene veze otkrivaju da se lagano distanciranje od konvencionalne religioznosti zbiva po obrascu koji je detektirala kontekstualna sekularizacijska teo- 
rija. Manje od desetine uzorka (8\%) nije bilo dodirnuto nijednim od triju indikatora (krštenje, odgoj u vjeri i vjeronauk) u svom djetinjstvu. Budući da u anketiranoj populaciji postoji opća proširenost dvaju indikatora konvencionalne religioznosti (krštenje i pohađanje vjeronauka) te većinska još dva (odgoj u vjeri i konfesionalna identifikacija), preostaje analizirati njihovu reprodukciju u indikatorima aktualne vezanosti. U kojoj se mjeri tradicionalna religioznost iz djetinjstva pretvara u aktualnu u studentskoj dobi? Koliko je onih koji ostaju vezani uz religiju i crkvu, a koliko onih koji se udaljavaju? U kojim se indikatorima aktualne religioznosti zadržala najčvršća vezanost, a u kojima je došlo do najvećeg udaljavanja?

Budući da se najveći dio ispitanika konfesionalno identificirao katolicima, pripadnicima religije s najrazrađenijim dogmatskim sustavom, propitivanje njihove dogmatske identifikacije iznimno je važno. Religijska vjerovanja mjerena su pomoću instrumenta koji se sastojao od četiriju indikatora prikazanih u tablici 4. Usporedo su prikazani i rezultati IDIS/Z-ovih nacionalnih istraživanja mladih iz $1985 .{ }^{11} \mathrm{i} 1999$. godine (Goja, 2000.) te 2012. godine (Ilišin i sur., 2013.). U svim je istraživanjima korišten isti instrument. ${ }^{12}$

Tablica 4.

Religijska vjerovanja (u \%)

\begin{tabular}{|c|c|c|c|c|c|}
\hline VJERUJETE LI DA: & GODINA ISTRAŽIVANJA & VJERUJE & SUMNJA & NE VJERUJE & B.0. \\
\hline \multirow{4}{*}{ POSTOJI BOG } & 1985. * & 19,6 & 24,4 & 56,0 & \\
\hline & 1999.* & 77,2 & 15,8 & 7,0 & \\
\hline & 2012. ** & 78,7 & 11,0 & 10,3 & \\
\hline & 2015. UNIRI & 53,7 & 28,3 & 16,7 & 1,3 \\
\hline \multirow{4}{*}{$\begin{array}{l}\text { BOG JE STVORIO } \\
\text { SVIJET }\end{array}$} & 1985. & 15,0 & 19,3 & 65,7 & \\
\hline & 1999. & 63,2 & 22,2 & 14,6 & \\
\hline & 2012. & 62,4 & 22,2 & 15,4 & \\
\hline & 2015. UNIRI & 28,4 & 36,2 & 34,0 & 1,4 \\
\hline \multirow{4}{*}{$\begin{array}{l}\text { POSTOJE RAJ I } \\
\text { PAKAO }\end{array}$} & 1985. & 9,7 & 18,2 & 72,1 & \\
\hline & 1999. & 50,6 & 33,0 & 16,4 & \\
\hline & 2012. & 62,3 & 24,2 & 13,5 & \\
\hline & 2015. UNIRI & 28,5 & 39,1 & 31,3 & 1,1 \\
\hline \multirow{4}{*}{$\begin{array}{l}\text { BOG JE IZVOR } \\
\text { MORALNIH PROPISA } \\
\text { I DUŽNOSTI }\end{array}$} & 1985. & 13,4 & 15,9 & 70,7 & \\
\hline & 1999. & 57,2 & 26,6 & 16,2 & \\
\hline & 2012. & 55,7 & 24,9 & 19,4 & \\
\hline & 2015. UNIRI & 30,4 & 38,6 & 29,9 & 1,1 \\
\hline
\end{tabular}

Izvori: *Goja, 2000.; **Ilišin i sur., 2013.

11 Budući da u istraživanju iz 1986. godine nije bilo ove baterije pitanja, koriste se izdvojeni rezultati kategorije mladih u istraživanju „Sociokulturni razvoj“, koje je proveo IDIS 1985. godine (Goja, 2000.).

12 Valja biti svjestan ograničenja usporedbe rezultata jer je nacionalni uzorak mladih uključivao i dio nepunoljetnih ispitanika, koji nisu obuhvaćeni ovim istraživanjem. Moguće je pretpostaviti da odgovori te skupine povećavaju razinu vjerovanja uzorka jer su oni pod većim utjecajem religioznosti roditelja nego je to slučaj sa studentskom populacijom. 
$\mathrm{Na}$ nacionalnom se planu odnos mladih prema religijskim vjerovanjima stubokom promijenio u devedesetima u odnosu na osamdesete godine prošloga stoljeća. Sredina osamdesetih razdoblje je u kojem je posustala ateizacija društva kroz represiju, ali se još uvijek sistemski favorizira nereligioznost i ateizam. U to vrijeme nijedno od ponuđenih vjerovanja ne prihvaća više od petine ispitanika, a tvrdnju da postoje raj i pakao prihvaća manje od desetine ispitanika. Petnaest godina kasnije sve su tvrdnje natpolovično prihvaćene, a najviše ona o postojanju Boga, u koju vjeruje tri četvrtine ispitanika. Analizirajući daljnji trend na temelju istraživanja iz 2012. godine može se zaključiti da je u segmentu religijskih vjerovanja među mladima na nacionalnoj razini došlo do stabilizacije (Ilišin i sur., 2013.), jer su promjene nakon trinaest godina minimalne.

Vjerovanje riječkih studenata u četiri ponuđene vjerske istine znatno je manje prošireno od nacionalnog prosjeka mladih. Najproširenije, i jedino natpolovično prihvaćeno, je vjerovanje u postojanje Boga. Ipak, značajan udio onih koji ne vjeruju i onih koji sumnjaju (45,0\%) dovodi u pitanje dijagnozu koju je Vrcan izrekao prije petnaest godina da je „vjerovanje u Boga postalo gotovo općeprihvaćenim sastojkom svjetonazorske društvene normalnosti“ (Vrcan, 2001.:76). Kod ostalih triju tvrdnji najbrojnija su kategorija oni koji sumnjaju, dok je udio onih koji vjeruju i onih koji ne vjeruju podjednak. Najviše ispitanika ne vjeruje da je Bog stvorio svijet $(34,0 \%)$, iz čega proizlazi da trećina ispitanika ne dijeli kršćansku ideju Boga. Studenti u sve tvrdnje manje vjeruju, više su neodlučni i više ne vjeruju. U tvrdnje Bog je stvorio svijet i Postoje raj i pakao studenti dvostruko manje vjeruju i dvostruko više ne vjeruju od prosjeka mladih u Hrvatskoj. Usporedba s rezultatima vjerovanja iz EVS-a provedenog 2008. godine moguća je samo u tvrdnji o postojanju Boga jer ostale tri tvrdnje u tom istraživanju nisu bile propitivane. Na nacionalnoj razini (Rimac, 2010.) udio onih koji vjeruju znatno je veći (86,9\%), udio onih koji sumnjaju ili ne znaju deset je puta manji $(2,8 \%)$, a udio onih koji ne vjeruju gotovo je dva puta manji $(9,0 \%)$ u odnosu na riječke studente. Možemo zaključiti da su riječki studenti, kada su u pitanju temeljna religijska vjerovanja, skeptičniji od prosjeka hrvatske populacije, ali i od prosjeka mladih.

T testom za nezavisne uzorke utvrđena je veza triju čestica skale sa spolom, a dviju s dijelom Hrvatske iz koje su ispitanici. Utvrđeno je da u tvrdnje: Postoji Bog ( $\mathrm{t}=-4,27$; $\mathrm{p}<, 001)$, Bog je stvorio svijet $(\mathrm{t}=-3,08 ; \mathrm{p}<, 01)$ i Postoje raj i pakao $(\mathrm{t}=-3,27 ; \mathrm{p}<$ ,01) više vjeruju žene nego muškarci. U tvrdnje da je Bog stvorio svijet $(\mathrm{t}=-3,05 ; \mathrm{p}<$

13 U postupku je najprije proveden test homogenosti varijanci i F-omjer, nakon toga je u slučaju homogenih varijanci proveden Scheffeov, a u slučaju nehomogenih varijanci Tamhaneov test, što je naznačeno u svakoj tablici. Viši rezultat aritmetičke sredine (M) u ovoj tablici znače i veću razinu vjerovanja $(1=$ ne vjerujem; $2=$ sumnjam; $3=$ vjerujem $)$

14 ,01) i Postoje raj i pakao $(\mathrm{t}=-2,92 ; \mathrm{p}<, 001)$ više vjeruju ispitanici iz krajeva koji su izravno bili zahvaćeni ratom nego iz drugih dijelova Hrvatske.

U tablici 5. prikazana je analiza varijance ${ }^{13}$ koja otkriva veze vjerovanja u tvrdnje Postoji Bog i Bog stvorio svijet ${ }^{14}$ sa socioekonomskim obilježjima ispitanika.

dentičnu vezu nalazimo i s tvrdnjom Postoje raj i pakao. 
Tablica 5.

Sociodemografske varijable i religijska vjerovanja

\begin{tabular}{|c|c|c|c|c|c|c|}
\hline & & M & SD & df & $\mathbf{F}$ & \\
\hline & POSTOJI BOG & & & & & \\
\hline \multirow{4}{*}{$\begin{array}{l}\text { VELIČINA } \\
\text { NASELJA } \\
\text { (Scheffe) }\end{array}$} & DO 1.000 STANOVNIKA & 2,48 &, 74 & \multirow{4}{*}{3} & \multirow{4}{*}{$4,294^{*}$} & \multirow{4}{*}{$1,2<3,4$} \\
\hline & $1.001-10.000$ STANOVNIKA & 2,45 &, 74 & & & \\
\hline & $10.001-100.000$ STANOVNIKA & 2,24 &, 77 & & & \\
\hline & VIŠE OD 100.000 STANOVNIKA & 2,38 &, 76 & & & \\
\hline \multirow{5}{*}{$\begin{array}{l}\text { OBRAZOVANJE } \\
\text { MAJKE } \\
\text { (Tamhane) }\end{array}$} & TROGODIŠNJA SREDNJA ŠKOLA & 2,56 & ,64 & \multirow{4}{*}{3} & \multirow{4}{*}{$7,965^{\text {*** }}$} & \multirow{4}{*}{$1,2<4$} \\
\hline & ČETVEROGODIŠNJA SREDNJA ŠKOLA & 2,46 &, 73 & & & \\
\hline & VIŠA ŠKOLA & 2,28 & ,79 & & & \\
\hline & FAKULTET & 2,15 & ,82 & & & \\
\hline & BOG JE STVORIO SVIJET & & & & & \\
\hline \multirow{4}{*}{$\begin{array}{l}\text { VELIČINA } \\
\text { NASELJA } \\
\text { (Tamhane) }\end{array}$} & DO 1.000 STANOVNIKA & 2,18 & ,82 & \multirow{4}{*}{3} & \multirow{4}{*}{$8,788^{* * *}$} & \multirow{4}{*}{$\begin{array}{c}1<3,4 \\
2<3\end{array}$} \\
\hline & $1.001-10.000$ STANOVNIKA & 1,99 &, 76 & & & \\
\hline & $10.001-100.000$ STANOVNIKA & 1,73 &, 77 & & & \\
\hline & VIŠE OD 100.000 STANOVNIKA & 1,81 &, 78 & & & \\
\hline \multirow{4}{*}{$\begin{array}{l}\text { OBRAZOVANJE } \\
\text { MAJKE } \\
\text { (Scheffe) }\end{array}$} & TROGODIŠNJA SREDNJA ŠKOLA & 2,22 &, 78 & \multirow{4}{*}{3} & \multirow{4}{*}{$7,916^{*}$} & \multirow{4}{*}{$1<3,4$} \\
\hline & ČETVEROGODIŠNJA SREDNJA ŠKOLA & 1,99 &, 78 & & & \\
\hline & VIŠA ŠKOLA & 1,80 &, 77 & & & \\
\hline & FAKULTET & 1,74 &, 78 & & & \\
\hline \multirow{4}{*}{$\begin{array}{l}\text { OBRAZOVANJE } \\
\text { OCA } \\
\text { (Scheffe) }\end{array}$} & TROGODIŠNJA SREDNJA ŠKOLA & 2,15 & ,83 & \multirow{4}{*}{3} & \multirow{4}{*}{$3,366^{* * *}$} & \multirow{4}{*}{$1<4$} \\
\hline & ČETVEROGODIŠNJA SREDNJA ŠKOLA & 1,93 &, 77 & & & \\
\hline & VIŠA ŠKOLA & 1,87 & ,81 & & & \\
\hline & FAKULTET & 1,85 &, 78 & & & \\
\hline
\end{tabular}

${ }^{*} \mathrm{p} \leq, 01 ;{ }^{* * *} \mathrm{p}<, 001$

Rastom veličine naselja u kojem su ispitanici odrasli smanjuje se vjerovanje, a raste nevjerovanje. Statistički značajna razlika postoji između ispitanika odraslih u naseljima do 10.000 stanovnika i onih odraslih u većim naseljima. Vjerovanje u dogme opada i porastom obrazovne razine oca i majke. Ispitanici čiji su roditelji obrazovaniji manje prihvaćaju dogme od ispitanika čiji su roditelji manje obrazovani. Utvrđene statističke veze tih varijabli sa sociodemografskim obilježjima ispitanika još jednom pokazuju da su u uzorku prisutni obrasci koji su detektirani kao manifestacije sekularizacijskih procesa. Dodatna provjera opravdanosti prethodnog zaključka izvršena je analizom indikatora religijskog ponašanja ispitanika. Kao pokazatelji religijskog ponašanja odabrano je prakticiranje dvaju činova pobožnosti i učestalost participiranja u crkvenim obredima.

Čini pobožnosti kao poželjni, ali ne i obvezni oblici religijskog ponašanja (Vrcan, 1980.) u upitniku su propitivani pitanjima o slavljenju vjerskih blagdana i postu prije njih (tablica 6.). 
Tablica 6.

Čini pobožnosti

\begin{tabular}{|l|c|c|c|}
\hline & NE & DA & B.0. \\
\hline SLAVITE LI VJERSKE BLAGDANE? & 13,5 & 83,6 & 2,9 \\
\hline POSTITE LI PRIJE BLAGDANA? & 51,9 & 45,2 & 2,9 \\
\hline
\end{tabular}

Slavljenje vjerskih blagdana opće je prošireno u neznatno manjem opsegu od najproširenijeg indikatora tradicionalne religioznosti - krštenja, što je pokazatelj široko prisutne religijski temperirane obiteljske atmosfere. Slavljenje blagdana statistički je povezano s krštenjem $(\mathrm{t}=-11,77, \mathrm{p}<0,001)$ i odgojem u vjeri $(\mathrm{t}=-8,32, \mathrm{p}<, 001)$. No, uz dominantnu tendenciju podudaranja, zanimljivija su odstupanja, i to u vidu proširenosti proslave vjerskih blagdana i među ispitanicima koji nisu bili religijski socijalizirani. Blagdane slavi gotovo polovina (43,8\%) onih koji nisu kršteni i preko dvije trećine $(70,4 \%)$ onih koji nisu odgajani u vjeri.

Post prije blagdana puno je manje prisutan u uzorku, a natpolovični dio ispitanih ne prakticira ga. Post je također povezan s krštenjem $(t=-6,128, \mathrm{p}<0,001)$ i odgojem $\mathrm{u}$ vjeri $(\mathrm{t}=-10,168, \mathrm{p}<, 001)$. Prije blagdana poste značajno više oni čija je obiteljska socijalizacija bila impregnirana religijom $(59,9 \%)$ u odnosu na one koji nisu bili religijski socijalizirani (18,9\%). Istodobno je gotovo polovično (40,2\%) prošireno nepridržavanje te zahtjevnije norme među onima koji su religijski socijalizirani.

Religijsko ponašanje mjereno je i učestalošću odlazaka na misu. Riječ je o „religijskom ponašanju čisto obredne naravi“, središnjem obliku institucionalne religioznosti kroz koji se iskazuje narav veze $s$ vjerskom organizacijom, odnosno postojanje crkvene religioznosti. U tablici 7. paralelno su prikazani rezultati učestalosti odlaska na mise riječkih studenata te nacionalnog istraživanja iz 2010. godine, koje je koristilo gotovo identičnu skalu (Nikodem, 2011.).

Tablica 7.

Koliko često idete na misu? (u \%)

\begin{tabular}{|l|c|c|}
\hline & UNIRI & HR \\
& 2015. & 2010. $^{*}$ \\
\hline NIKADA & 34,7 & 8,5 \\
\hline JEDNOM U NEKOLIKO GODINA & - & 12,9 \\
\hline SAMO NA VELIKE BLAGDANE & 42,5 & 40,9 \\
\hline NEKOLIKO PUTA MJESEČNO & 14,5 & 12,8 \\
\hline BAREM JEDNOM TJEDNO & 7,4 & 22,9 \\
\hline B.0. & 0,9 & - \\
\hline
\end{tabular}

* Izvor: Nikodem, 2011. 
Najviše anketiranih studenata smjestilo se u kategoriju prigodnih - blagdanskih praktikanata, a riječ je o prakticiranju dvaju obreda (o Uskrsu i Božiću). Druga je po veličini kategorija neprakticirajućih, koji nikada ne sudjeluju u obredima. Slijede oni koji misama prisustvuju mjesečno - povremeni praktikanti, a najmanje je onih koji se pridržavaju crkvenog zahtjeva te dolaze na obrede barem jednom tjedno redoviti praktikanti. Dakle obredna aktivnost anketiranih ponajviše je prigodna, a čak trećina uopće ne participira u obredima. Češća povezanost s religijom i crkvom kroz obrede značajka je samo petine ispitanika. Kada rezultate riječkih studenata usporedimo s učestalošću prisustvovanja obredima cjelokupne hrvatske populacije (Nikodem, 2011.), nalazimo da je u kategoriji redovitih praktikanata tri puta manje, među prigodnima podjednako, a među apstinentima četiri puta više studenata od nacionalnog prosjeka. Dakle riječki su studenti značajno neaktivniji od nacionalnog prosjeka u ritualnoj dimenziji.

Što otkrivaju IDIZ/S-ova generacijska istraživanja o trendovima dominikalne prakse među mladima i studentima u posljednjih tridesetak godina? ${ }^{15}$ Religijsko ponašanje mladih u Hrvatskoj, uostalom kao i cijele populacije, bilježi veliki obrat na prijelazu iz osamdesetih u devedesete godine dvadesetog stoljeća (Marinović Jerolimov, 2002.). U tom se razdoblju broj redoviti(ji)h praktikanata (kategorija često) podvostručuje, te postaje najbrojnija kategorija, a broj se apstinenata prepolovljuje. ${ }^{16}$ U sljedećem istraživanju (Ilišin i Radin, 2007.) broj redovitih praktikanata na nacionalnoj razini smanjuje se na udio koji je imao u osamdesetima, te opet postaje manji od preostalih dvaju modaliteta. Razlika se prelijeva u rast prigodno prakticirajućih, koji sada čine natpolovični dio populacije. Neznatne promjene, u vidu blagog porasta onih koji su redovitiji praktikanti, vidimo u rezultatima istraživanja iz 2012. godine (Ilišin i sur., 2013.). Rezultati tog istraživanja sugerirali su da je došlo do stabilizacije vjerničke strukture među mladima kada je u pitanju ritualna dimenzija crkvenosti. Međutim velika promjena slijedi u istraživanju provedenom 2013. godine, kada se gotovo podvostručuje udio apstinenata, te oni postaju najbrojnija kategorija.

15 U istraživanjima mladih (Ilišin i Radin, 2007.; Ilišin i Spajić Vrkaš, 2015.) i studenata (Ilišin, 2014.) korištena je skala s trima modalitetima odgovora: nikad, ponekad i često, dok je u istraživanju iz 2012. godine (Ilišin i sur., 2013.) dodana i četvrta kategorija redovito. U ovom je istraživanju korištena skala koju su koristila i prva dva nacionalna istraživanja (Goja, 2000.), a da bi bila moguća usporedba s ostalim istraživanjima sažeta je tako da zbroj kategorija više puta tjedno, jedanput tjedno i jednom do dva puta mjesečno čine kategoriju često, samo o većim blagdanima odgovara kategoriji ponekad, a ne idem kategoriji nikada, dok je u četveročlanoj skali redovito pribrojeno modalitetu često.

16 S obzirom na naš uzorak, valja imati na umu da su i tada mladi u Istri i Primorju iskazivali znatno manju razinu crkvene aktivnosti od prosjeka (Marinović Jerolimov, 2002.:103). 
Tablica 8.

Odlasci mladih i studenata na misu (u \%)

\begin{tabular}{|c|c|c|c|c|c|}
\hline & GODINA ISTRAŽIVANJA & NIKADA & PONEKAD & ČESTO & B.0. \\
\hline \multirow{5}{*}{ MLADI } & 1986.* & 45,3 & 33,2 & 21,2 & 0,3 \\
\hline & 1999.* & 20,3 & 37,4 & 41,8 & 0,5 \\
\hline & $2004 . * *$ & 24,4 & 53,6 & 21,6 & 0,4 \\
\hline & $2012 . * * *$ & 23,0 & 51,2 & 25,7 & 0,1 \\
\hline & 2013.**** & 42,8 & 40,0 & 17,3 & - \\
\hline \multirow{2}{*}{ STUDENTI } & 2010. ***** & 42,1 & 36,9 & 21,1 & - \\
\hline & 2015. UNIRI & 34,7 & 42,5 & 21,9 & 0,9 \\
\hline
\end{tabular}

Izvori: *Goja, 2000.; **Ilišin i Radin, 2007.; ***Ilišin i sur., 2013.; ****Ilišin i Spajić Vrkaš, 2015.; *****Ilišin, 2014.

Je li ta drastična promjena u religijskom ponašanju povezana s promjenom percepcije Crkve, jer u to vrijeme istraživanja bilježe pad povjerenja u nju kao instituciju? U kojoj je mjeri ta promjena povezana sa slabljenjem neformalnog društvenog pritiska i favoriziranja religije i crkve? U svakom slučaju, udio redovitih praktikanata opada te je sad ispod udjela koji je ta kategorija imala sredinom osamdesetih godina u socijalizmu. Iz rezultata navedenih istraživanja nedvojbeno je da se zbivaju velike oscilacije u religijskom ponašanju mladih. Redovitost religijske participacije hrvatskih studenata iz istraživanja provedenog 2010. godine odgovara religijskom ponašanju mladih iz 2013. godine, a jako se razlikuje od onog iz 2012. godine (Ilišin i Spajić Vrkaš, 2015.). Znači li to da je apostaza najprije zahvatila studentsku populaciju, a nakon toga se širi na čitavu generaciju? Može li se govoriti o načelu obrazovne stratificirane difuzije, prema kojem će se promjene koje se događaju danas u najobrazovanijem dijelu mladih sutra preliti na generaciju u cijelosti? Rezultati dominikalne prakse riječkih studenata uklapaju se u one dobivene u istraživanju studentske populacije na razini Hrvatske, uz obrnuti postotak apstinenata i povremenih (blagdanskih) praktikanata, što ih čini neznatno religijski aktivnijima od studentskog prosjeka.

Sociodemografske varijable povezane s varijablom dominikalne prakse su spol, obrazovanje majke, veličina naselja odrastanja i dio Hrvatske iz kojeg ispitanik dolazi. T test za nezavisne uzorke otkriva $(\mathrm{t}=-2,34 ; \mathrm{p}=, 01)$ da je studentica značajno manje od studenata među nepraktikantima $(29,8 \%: 42,7 \%)$. No to ne znači da su studentice redovite praktikantice, i kod njih je dominantan oblik ponašanja blagdanska obredna participacija (47,3\%). S rastom majčina obrazovanja smanjuje se udio prigodnih i povremenih praktikanata, a povećava udio apstinenata $(\mathrm{C}=, 21 ; \mathrm{p}<, 01)$. U ispitanika čije su majke fakultetski obrazovane najveća su kategorija apstinenti, dok su u ostalim skupinama to prigodni praktikanti. Nanovo se iskazuje razlika između ispitanika iz krajeva zahvaćenih ratnim zbivanjima i ostalih $(\mathrm{t}=-2,45 ; \mathrm{p}=, 01)$, na način da se u krajevima koji nisu imali izravnih ratnih djelovanja više apstinira i rjeđe participira u misama. 
Tablica 9.

Veličina naselja i odlazak na misu

\begin{tabular}{|c|c|c|c|c|c|c|}
\hline & & M & SD & df & $\mathbf{F}$ & \\
\hline \multirow{4}{*}{$\begin{array}{l}\text { VELIČINA } \\
\text { NASELJA } \\
\text { (Scheffe) }\end{array}$} & DO 1.000 STANOVNIKA & 2,22 & ,89 & \multirow{4}{*}{3} & \multirow{4}{*}{8,207} & \multirow{4}{*}{$1<3,4$} \\
\hline & $1.001-10.000$ STANOVNIKA & 1,98 & ,91 & & & \\
\hline & $10.001-100.000$ STANOVNIKA & 1,79 & ,88 & & & \\
\hline & VIŠE OD 100.000 STANOVNIKA & 1,74 &, 78 & & & \\
\hline
\end{tabular}

$\mathrm{p}<, 001$

Analiza varijance (tablica 9.) otkriva smanjenje učestalosti odlazaka na misu i rast apstinencije u svakoj većoj kategoriji naselja prebivališta. Razliku nalazimo između ispitanika iz najmanjih naselja i dviju najvećih kategorija. Redovitih praktikanata tri je puta više među onima iz najmanjih naselja (10,8\%) nego među onima iz najvećih naselja (3,2\%). Hi kvadrat test ukazao je na, doduše nejaku, indikativnu statističku vezu ispitanikove procjene imovinskog stanja svoje obitelji i učestalosti dominikalne prakse $(\mathrm{C}=, 17 ; \mathrm{p}<, 01)$. Veza je u skladu s Inglehartovom tezom o povezanosti egzistencijalne nesigurnosti i religioznosti. Ispitanici koji svoje stanje ocjenjuju lošijim od prosjeka dvostruko su češće redoviti praktikanti od ostalih ispitanika.

Kakve su veze tradicionalne religioznosti i dominikalne prakse? Koliko se obiteljska religijska socijalizacija u djetinjstvu održava u studentskoj dobi? Analiza veze tradicionalne religioznosti i učestalosti aktualne crkvene participacije otkriva nekonzistentnost u crkvenoj religioznosti ispitanika. Korelacija varijabli konfesionalna identifikacija i dominikalna praksa $(\mathrm{C}=, 40 ; \mathrm{p}<, 001)$ potvrđuje prethodno iznijetu tezu da konfesionalna samoidentifikacija nije pouzdan indikator religioznosti. Naime tek svaki deseti deklarirani katolik $(10,1 \%)$ redovito (tjedno) sudjeluje na misama, svaki drugi (48,62\%) samo na velike blagdane, a svaki peti (22,0\%) nikada. Najdosljedniji su ateisti, kojih ipak desetina (8,7\%) participira na misama, i to samo na velike blagdane. Zagonetna skupina onih koji nisu odgovorili na pitanje o konfesionalnoj identifikaciji u ogromnoj većini apstinira $(45,2 \%)$ ili participira u obredima samo prigodno na blagdane (32,6\%). Na temelju tog indikatora religijskog ponašanja može se zaključiti da najveći dio ispitanika koji se nisu konfesionalno svrstali ima vrlo slabu vezu s vjerskom zajednicom. T testom utvrdene su veze indikatora tradicionalne obiteljske religioznosti i dominikalne prakse. Kršteni $(\mathrm{t}=-5,659$; $\mathrm{p}<, 001)$ i odgajani u vjeri $(t=-11,857$; $\mathrm{p}<, 001)$ očekivano su redovitiji praktikanti od nekrštenih i onih koji nisu odgajani u vjeri. Što otkrivaju križanja o konverziji ponašanja u odnosu na obiteljsku atmosferu u djetinjstvu? Dvije trećine ispitanika (75\%) koji nisu kršteni nisu ni praktikanti, a oni koji participiraju u obredima to čine uglavnom samo na velike blagdane. Redovitih praktikanata među onima koji su kršteni manje je od desetine (7,6\%), većina participira blagdanski (46,2\%), a gotovo trećina (30,6\%) u potpunosti apstinira. Dakle uključivanje u Crkvu obredom krštenja jest povezano $s$ razlikama u učestalosti religijske participacije, ali nije jamstvo redovitosti kasnijeg religijskog ponašanja. 
Dva od tri ispitanika koji nisu religijski odgajani (68,04\%) nikada ne idu na misu, a nešto više od četvrtine $(27,8 \%)$ prisustvuje misi povremeno, samo na velike blagdane. Svaki peti religijski odgajani ispitanik $(19,9 \%)$ apstinent je, a svaki drugi prigodni (blagdanski) praktikant. Petina odgajanih u vjeri prisustvuje misama mjesečno, a desetina tjedno. Obiteljska transmisija (ne)religioznosti nije bila odviše uspješna kada je riječ o (ne)prisustvovanju obredima u studentskoj dobi. Možemo zaključiti da je nedosljednost između obiteljske socijalizacije i aktualnog ponašanja prisutna u objema skupinama, među onima koji nisu i onima koji jesu religijski socijalizirani. Misama prisustvuje četvrtina nekrštenih, petina onih koji ne slave vjerske blagdane i trećina onih koji nisu vjerski odgajani. No vezu s vjerskom zajednicom ogromna većina njih održava samo prigodno - na velike blagdane. U misama nikad ne participira trećina krštenih i petina odgojenih u vjeri. Dakle nezanemariv dio onih koji imaju iskustvo obiteljske religijske atmosfere ima sporadičnu vezu s vjerskom zajednicom ili se od nje otudio.

Veza između dvaju oblika religijskog ponašanja, odlazaka na mise i slavljenja velikih crkvenih blagdana otkriva daljnje nekonzistentnosti. Svaki sedmi ispitanik $(14,29 \%)$ koji ne slavi vjerske blagdane ipak u to vrijeme prisustvuje misi, a nešto više od četvrtine $(28,1 \%)$ onih koji slave vjerske blagdane nikada ne prisustvuje misi. U prvom je slučaju riječ o nereligijskim, vjerojatno konformističkim motivima obrednog ponašanja, a u drugom je slavljenje blagdana izgubilo vezu s institucijom.

Pretače li se dogmatska identifikacija u dominikalnu praksu? U kojoj su mjeri ispitanici koji vjeruju povezani s vjerskom zajednicom? Jesu li i koliko oni koji sumnjaju i oni koji ne vjeruju obredno aktivni? U tablici 10. prikazana je analiza varijance za dvije varijable, a sličan je odnos i u preostalim dvjema, gdje veći rezultat aritmetičke sredine znači učestaliju dominikalnu praksu. Kod svih je vjerskih istina vidljivo da njihovim prihvaćanjem raste i redovitost obredne aktivnosti. Što je s konzistentnošću (ne)vjerovanja i ponašanja? Naglasit ćemo samo one postotke koji pokazuju nesklad (ne)vjerovanja i obrednog ponašanja, posebice u rubnim skupinama. Šestina $(16,2 \%)$ onih koji vjeruju u Boga nikad ne participira u vjerskim obredima, pa možemo zaključiti da je riječ o skupini koju karakterizira „vjerovanje bez pripadanja“ (Davie). Istodobno, najveća skupina u toj kategoriji, nešto manje od polovine (46,6\%), vezu s vjerskom zajednicom održava samo u vrijeme velikih blagdana. S druge strane, nešto manje od petine (17,9\%) onih koji ne vjeruju u Boga i polovina onih koji sumnjaju $(51,4 \%)$ participira u obredima, i to većinom na velike blagdane. Je li riječ o kategoriji blagdanskih ritualista koji sporadično pripadaju, ali ne vjeruju?

Gledano s aspekta prakticiranja, redoviti praktikanti gotovo apsolutno vjeruju u postojanje Boga (98\%), ali kada je u pitanju Božje stvaranje svijeta nesigurnost raste $(17,4 \%)$. Da postoji Bog vjeruje i desetina nepraktikanata, a još četvrtina nije sigurna. Postojanje raja i pakla najproblematičnija je vjerska istina, u koju ne vjeruje nešto manje od desetine $(8,7 \%)$, a sumnja desetina $(10,9 \%)$ redovitih praktikanata. No istodobno u nju vjeruje svaki šesnaesti (6,4\%), a nije siguran svaki treći $(31,7 \%)$ apstinent. Blagdanski praktikanti većinski vjeruju samo u postojanje Boga, dok u sve ostale dogme većinski sumnjaju. Sumnja se u blagdanskih praktikanata kreće od trećine $(34,1 \%)$ u postojanje Boga do polovine $(51,3 \%)$ u postojanje raja i pakla. 
Tablica 10.

Religijska vjerovanja i odlazak na misu

\begin{tabular}{|c|c|c|c|c|c|c|}
\hline & & M & SD & df & $\mathbf{F}$ & \\
\hline \multirow{3}{*}{$\begin{array}{l}\text { POSTOJI BOG } \\
\text { (Tamhane) }\end{array}$} & NE VJERUJEM & 1,19 &, 42 & \multirow{3}{*}{2} & \multirow{3}{*}{$111,540^{*}$} & \multirow{3}{*}{$\begin{aligned} 1 & <2,3 \\
2 & <3\end{aligned}$} \\
\hline & NE ZNAM, NISAM SIGURAN & 1,64 &, 62 & & & \\
\hline & VJERUJEM & 2,34 & ,90 & & & \\
\hline \multirow{3}{*}{$\begin{array}{l}\text { BOG JE STVORIO } \\
\text { SVIJET } \\
\text { (Tamhane) }\end{array}$} & NE VJERUJEM & 1,37 &, 56 & \multirow{3}{*}{2} & \multirow{3}{*}{$117,760^{*}$} & \multirow{3}{*}{$\begin{array}{c}1<2,3 \\
2<3\end{array}$} \\
\hline & NE ZNAM, NISAM SIGURAN & 2,02 &, 74 & & & \\
\hline & VJERUJEM & 2,54 & ,96 & & & \\
\hline
\end{tabular}

$* \mathrm{p}<, 001$

Sljedeći je korak u analizi religioznosti studenata religijska samoidentifikacija, odnosno samosvrstavanje ispitanika na kontinuumu vjera - ateizam. U upitniku je korištena petostupanjska skala čiji su polovi uvjereni/a ateist/ica - uvjereni/a vjernik/ica. Čulig, Kufrin i Landripet kreirali su tu skalu u istraživanju „Odnos građana prema članstvu Republike Hrvatske u Europskoj uniji“ (2007.). Taj se instrument čini najprimjerenijim jer ispitaniku na objema stranama skale nudi dva stupnja za samopozicioniranje, za razliku od skale EIV-a, koja na nereligioznoj strani ima dva, a nereligioznoj strani skale samo jedan modalitet, te ne uključuje mogućnost pozicioniranja onih koji su neodlučni. IDIS/Z-ova, najčešće korištena skala u istraživanjima religioznosti u Hrvatskoj, u religioznim modalitetima skale mjeri dodatnu dimenziju - odnos prema vjerskom učenju, a u nereligioznim modalitetima odnos prema religiji, koji se može interpretirati i kao odnos prema vjerskim organizacijama. Rezultati su prikazani u tablici 11., usporedo s rezultatima istraživanja na nacionalnom uzorku iz 2007. godine.

Tablica 11.

Procijenite svoj odnos prema vjeri

\begin{tabular}{|l|c|c|}
\hline & $\begin{array}{c}\text { UNIRI } \\
2015 .\end{array}$ & $\begin{array}{c}\text { HRVATSKA } \\
\text { 2007. }^{*}\end{array}$ \\
\hline UVJEREN/A ATEIST/ICA & 14,2 & 4,2 \\
\hline MNOGO SKLONIJI/JA NEVJEROVANJU NEGO VJEROVANJU & 17,5 & 4,7 \\
\hline NE ZNAM, NE MOGU PROCIJENITI & 15,1 & 8,0 \\
\hline MNOGO SKLONIJI/JA VJEROVANJU NEGO NEVJEROVANJU & 30,9 & 36,6 \\
\hline UVJEREN/A VJERNIK/CA & 21,4 & 46,4 \\
\hline B.0. & 0,9 & 0,1 \\
\hline
\end{tabular}

*Izvor: Čulig, Kufrin i Landripet, 2007.

Natpolovična većina anketiranih studenata smjestila se na vjerničku stranu skale, više u umjereniji nego krajnji modalitet. Nešto manje od trećine ispitanika smjestilo se na drugoj strani skale, također više u umjereniji nego u krajnji modalitet. Dakle nešto više od polovine anketiranih sebe doživljava kao vjernike, a trećina kao ne- 
vjernike. Prije usporedbe ${ }^{17}$ religijske samoidentifikacije studenata s nacionalnim prosjekom valja primijetiti da rezultati dobiveni istim instrumentom ne odskaču bitno od onih utvrđenih nacionalnim istraživanjima koja su koristila drugačije skale. ${ }^{18}$ Riječki se studenti u odnosu na opću populaciju u Hrvatskoj značajno manje svrstavaju u vjerničke modalitete, razlika je čak minus 30,7\%. U kategoriju uvjerenih vjernika smjestilo se tri i pol puta manje studenata nego ispitanika u nacionalnom uzorku, a istodobno ih je tri i pol puta više u kategorijama u nereligioznom dijelu skale. Razlikuju li se riječki studenti po tome od mladih u Hrvatskoj i od studentskog prosjeka? Prije odgovora na to pitanje valja barem kratko problematizirati trendove religijske samoidentifikacije mladih (tablica 12.) na temelju IDIS/Z-ovih istraživanja, i to podacima u kojima su povezane dvije vjerničke i dvije nevjerničke kategorije u jednu.

Tablica 12.

Sažeta religijska samoidentifikacija (u \%)

\begin{tabular}{|c|c|c|c|c|c|}
\hline & $\begin{array}{c}\text { GODINA } \\
\text { ISTRAŽIVANJA }\end{array}$ & RELIGIOZAN & $\begin{array}{l}\text { NEODLUČAN/ } \\
\text { RAVNODUŠAN }\end{array}$ & NERELIGIOZAN & B. 0 . \\
\hline \multirow{4}{*}{ MLADI } & 1986.* & 28,3 & 23,3 & 47,2 & 1,2 \\
\hline & 1999.* & 66,4 & 19,7 & 13,6 & 0,4 \\
\hline & 2004. ** & 73,1 & 16 & 10,1 & 0,9 \\
\hline & 2013.**** & 59,7 & 19,1 & 21,2 & - \\
\hline \multirow{2}{*}{ STUDENTI } & 2010. $* * * * *$ & 57,3 & 24,3 & 18,4 & - \\
\hline & 2015. UNIRI & 52,3 & 15,1 & 31,7 & 0,9 \\
\hline
\end{tabular}

Izvori: *Goja, 2000.; **Ilišin i Radin, 2007.; ****Ilišin i Spajić Vrkaš, 2015.; ***** Ilišin, 2014.

${ }^{17}$ Budući da je istraživanje s kojim je moguće, zbog korištenja istog instrumenta mjerenja, uspoređivati rezultate provedeno osam godina prije ovog, nameće se pitanje jesu li usporedbe zbog protoka vremena opravdane. Zbivaju li se u posljednjih desetak godina neke promjene koje mijenjaju prethodnu sliku religioznosti? Ukoliko se pođe od teze da se sitne promjene događaju, ali da je opća situacija nepromijenjena, onda su usporedbe umjesne. No ukoliko se krene od pretpostavke da drastična promjena religijske vezanosti početkom devedesetih nije bila isključivo stabilizacija vjerničke strukture koju je socijalizam egzogeno, ali i endogeno narušio, već i posljedica trenutnih povijesnih okolnosti koje su potencirale religioznost (rat, konfesionalno kao dio kolektivnog identiteta koji „nas“ razlikuje od „njih“), a da promjena okolnosti i protok vremena od traumatičnih događaja ostavljaju tragove i na religioznosti, onda s usporedbama istraživanja između kojih je prošlo toliko vremena treba biti oprezan. Alternativni pristup, kojem u prilog idu i prije izložene promjene religijske participacije mladih, najavljuje promjene u religioznosti stabilizacijom tranzicijskog konteksta (Cifrić, 1995 ; Boneta, 2000.; Marinović Jerolimov, 2002.; Nikodem, 2011.). No ukoliko se želi naglasiti religijske razlike studentske u odnosu na opću populaciju i u odnosu na mlade uopće, ne preostaje drugo nego, uz naglašenu rezervu zbog protoka vremena i mogućih promjena koje su se dogodile, usporediti rezultate.

\section{8}

8 Udio religioznih u nacionalnim istraživanjima kreće se između 80 i 90\%, a udio nereligioznih između 7 i 14\%. Primjerice EVS iz 2008. godine nalazi 79\% religioznih, 10\% nereligioznih, 4\% uvjerenih ateista i 6\% odgovara odgovorom „ne znam“ (Črpić i Zrinščak, 2010.). Istraživanje provedeno 2010. godine (Nikodem, 2011.) nalazi $47,2 \%$ religioznih u skladu s crkvenim učenjem, 41,6\% religioznih na svoj način, 3,8\% neodlučnih, 7,1\% nereligioznih i $0,3 \%$ protivnika religije. 
„Početno stanje“ sredinom osamdesetih karakterizirala je gotovo polovina nereligioznih ispitanika te neznatno više religioznih nego neodlučnih i ravnodušnih. Rezultati istraživanja iz 1999. pokazuju da je došlo do „bitnog zaokreta od nereligiozne prema religioznoj orijentaciji mladih u Hrvatskoj" (Goja, 2000.:151). Dvije trećine mladih svrstalo se u religiozne (podjednako u oba modaliteta), što je dva i pol puta više nego sredinom osamdesetih, dok se udio nereligioznih smanjio tri i pol puta. Trend rasta religiozne identifikacije na nacionalnoj razini nastavlja se i u istraživanju iz 2004. godine (Ilišin i Radin, 2007.), kada se u tim kategorijama identificira gotovo tri četvrtine ispitanika, a udio nereligioznih pada na desetinu. U ovom istraživanju kategorija uvjerenih vjernika postaje najveća u uzorku. U istraživanju iz 2013. godine (Ilišin i Spajić Vrkaš, 2015.) udio se religioznih smanjuje ispod udjela koji je ta kategorija imala 1999. godine, a njena se unutarnja struktura mijenja u korist religioznih koji ne prihvaćaju sve što njihova vjera uči. Istodobno se udio nereligioznih udvostručuje, a u njemu se opet pojavljuje, u prethodnim istraživanjima gotovo iščezla, kategorija protivnika religije. Sličnu distribuciju nalazimo i u istraživanju studenata iz 2010. godine (Ilišin, 2015.), uz veći udio neodlučnih nego ravnodušnih u srednjoj kategoriji. Nažalost, u prikazu tih rezultata ne nalazimo razlike u religioznosti po sveučilištima, pa ne možemo znati jesu li se tada riječki studenti razlikovali od hrvatskog studentskog prosjeka. ${ }^{19}$ Riječki su se studenti u istraživanju iz 2015. godine više smjestili u dvije kategorije nereligioznih (+13,3\%), a manje među neodlučne $(-9,2 \%)$ i među dvije kategorije religioznih $(-5,0 \%)$ od studentskog prosjeka iz 2010. godine. Dakle mladi se znatno manje identificiraju religioznima, a više nereligioznima od cjelokupne hrvatske populacije. Riječki se studenti pak još više identificiraju nereligioznima, a manje religioznima od studentskog prosjeka i prosjeka mladih.

Statistička je analiza izdvojila pet sociodemografskih varijabli povezanih s religijskom samoidentifikacijom: spol $(\mathrm{t}=-4,343 ; \mathrm{p}<, 001)$; područje studija $(\mathrm{t}=2,363 ; \mathrm{p}$ $<, 05)$; dio Hrvatske iz kojeg ispitanik dolazi $(\mathrm{t}=-2,00 ; \mathrm{p}<, 05)$; veličinu naselja $\mathrm{i}$ obrazovnu razinu majke. Sukladno nalazima većine dosadašnjih istraživanja (Voas, McAnrew i Storm, 2013.), studentice se češće identificiraju religioznima (59,4\% : $42,6 \%$ ), a manje nereligioznima (25,8\% : 41,3\%) nego studenti. Studenti su se podijelili u dvije podjednako velike skupine religioznih i nereligioznih, dok je studentica gotovo dva i pol puta više među religioznima nego među nereligioznima. Studenti na fakultetima prirodoslovnog i tehničkog usmjerenja manje se svrstavaju u uvjerene vjernike, a više u uvjerene ateiste od studenata društvenih i humanističkih studija. Prva razlika u religijskoj samoidentifikaciji ispitanika s obzirom na dio Hrvatske iz kojeg potječu je da se oni iz područja s ratnim iskustvom više svrstavaju u religiozne, a manje u neodlučne od onih bez tog iskustva. Druga je razlika vidljiva u strukturi religioznih, gdje se prvi više svrstavaju u krajnju kategoriju uvjerenih vjernika, a drugi u kategoriju onih koji su bliže vjerovanju nego nevjerovanju.

19 Jedini indikator razlike je da oni, uz zagrebačke studente, manje od ostalih zastupaju tradicionalističku interesnu orijentaciju, koja uključuje interes za vjeru i vjerski život, iz čega bi se moglo zaključiti da su manje religiozni od prosjeka. 
Tablica 13.

Sociodemografske varijable i religijska samoidentifikacija

\begin{tabular}{|c|c|c|c|c|c|c|}
\hline & & M & SD & df & $\mathbf{F}$ & \\
\hline \multirow{4}{*}{$\begin{array}{l}\text { VELIČINA } \\
\text { NASELJA } \\
\text { (Scheffe) }\end{array}$} & DO 1.000 STANOVNIKA & 3,53 & 1,29 & \multirow{4}{*}{3} & \multirow{4}{*}{$3,508^{*}$} & \multirow{4}{*}{$1>3$} \\
\hline & $1.001-10.000$ STANOVNIKA & 3,32 & 1,37 & & & \\
\hline & $10.001-100.000$ STANOVNIKA & 3,02 & 1,37 & & & \\
\hline & VIŠE OD 100.000 STANOVNIKA & 3,16 & 1,35 & & & \\
\hline \multirow{4}{*}{$\begin{array}{l}\text { OBRAZOVANJE } \\
\text { MAJKE } \\
\text { (Tamhane) }\end{array}$} & TROGODIŠNJA SREDNJA ŠKOLA & 3,66 & 1,19 & \multirow{4}{*}{3} & \multirow{4}{*}{$5,133^{* * *}$} & \multirow{4}{*}{$1>3,4$} \\
\hline & ČETVEROGODIŠNJA SREDNJA ŠKOLA & 3,36 & 1,35 & & & \\
\hline & VIŠA ŠKOLA & 3,07 & 1,31 & & & \\
\hline & FAKULTET & 3,03 & 1,46 & & & \\
\hline
\end{tabular}

$* \mathrm{p}<, 05 ; * * \mathrm{p}<, 01$

Analiza varijance otkrila je vezu veličine naselja i obrazovanja majke s religijskom samoidentifikacijom (tablica 13.). Vidljivo je da religioznost opada s porastom veličine naselja, a statistički značajna razlika postoji između ispitanika iz najmanjih naselja i onih srednje velikih. S porastom majčine razine obrazovanja smanjuje se religiozna samoidentifikacija, a razlika postoji između studenata čije su majke najniže razine obrazovanja i onih čije su majke završile višu i visoku školu. U kategoriji ispitanika čije su majke najslabije obrazovane tri je puta više religioznih nego nereligioznih, dok je u kategoriji najobrazovanijih između njih minimalna razlika. Zanimljivo je da statistička veza nije utvrđena kada je u pitanju obrazovanje oca, što ponovno upućuje na važniju ulogu majki u religijskoj socijalizaciji djece.

Relativno visoka korelacija ( $\mathrm{C}=, 47$; $\mathrm{p}<, 001)$ postoji između varijabli konfesional$n^{20}$ i religijske identifikacije. Usprkos utvrđenoj vezi i dalje stoji zaključak da konfesionalnu identifikaciju ne treba uzimati kao pouzdan, a pogotovo ne kao neupitan indikator religioznosti. Naime više od trećine (38,9\%) konfesionalno identificiranih ne svrstava se ni u jedan od dvaju religioznih modaliteta, a petina (21,51\%) se smješta u nereligiozne modalitete. Nešto više od trećine $(37,8 \%)$ iz kategorije onih koji nisu odgovorili na pitanje o konfesionalnosti svrstali su se u nereligiozne, nešto manje od polovine u religiozne $(44,4 \%)$, a najmanje $(15,6 \%)$ u neodlučne. Najdosljedniji su oni koji se nisu konfesionalno identificirali, koji su se većinski $(88,9 \%)$ smjestili u dva nereligiozna modaliteta, a zanemarivo $(3,2 \%)$ u one sklonije vjerovanju.

T test nalazi statistički značajne razlike i s preostalim dvama indikatorimaa tradicionalne obiteljske religioznosti: krštenjem $(\mathrm{t}=-4,726 ; \mathrm{p}<, 001)$ i odgojem u vjeri $(\mathrm{t}=$ -13,165; p < ,001). U obama mjerenim indikatorima ispitanici koji imaju iskustvo religijske socijalizacije imaju višu aritmetičku sredinu u odgovorima od onih koji nisu imali to iskustvo. Gledajući postotnu distribuciju primjetna je konverzija ispitanika

20 Varijabla je zbog korektnosti statističke obrade dekodirana i sažeta iz šest u tri kategorije: konfesionalno identificirani, konfesionalno neidentificirani i oni koji nisu odgovorili na to pitanje. 
u odnosu na izloženost (ne)religijskoj socijalizaciji u obitelji, i to u obama smjerovima. Trećina ispitanika koji nisu kršteni $(32,8 \%)$ svrstala se među religiozne, dok se neznatno manje krštenih (29,8\%) svrstalo u nereligiozne. Nešto više od petine $(22,1 \%)$ onih koje roditelji nisu odgajali u vjeri svrstava se u religiozne, a nešto manji postotak odgajanih u vjeri $(18,5 \%)$ svrstava se u nereligiozne. Sudeći po tom indikatoru, (ne)religijska obiteljska socijalizacija utječe na (ne)religioznu identifikaciju u godinama adolescencije, ali nikako nije riječ o neupitnoj evoluciji tradicionalne religioznosti u aktualnu. Sličan se zaključak nameće i nakon analiza veze pohađanja vjeronauka i religijske samoidentifikacije $(\mathrm{C}=, 41 ; \mathrm{p}<001)$. Očekivano, identifikacija u religijskim modalitetima raste, a u nereligijskim pada kako raste duljina pohađanja školskog vjeronauka. Primjerice tri četvrtine $(72,7 \%)$ onih koji nisu nikad pohađali vjeronauk svrstava se u nereligiozne, a dvije trećine $(63,7 \%)$ onih koji su ga pohađali tijekom cijelog školovanja svrstavaju se u religiozne. Zanimljivo da je religiozna identifikacija natpolovična jedino u toj kategoriji, a u njoj nalazimo i petinu $(21,6 \%)$ onih koji se deklariraju nereligioznima te sedminu $(14,7 \%)$ neodlučnih. Ispitanici koji su pohađali vjeronauk samo tijekom osnovnoškolskog školovanja podjednako se svrstavaju u religiozne $(42,4 \%)$ i nereligiozne $(41,3 \%)$.

Statistička analiza utvrdila je jaku vezu između religijske samoidentifikacije i odlazaka na misu (tablica 14.). Najveću dosljednost identifikacije i ponašanja nalazimo u uvjerenih ateista, gdje najmanje ispitanika $(8,9 \%)$ u ponašanju odstupa od svoje deklaracije, i to tako što misi prisustvuju na velike blagdane. To čini i znatan dio ispitanika (40,5\%) među umjerenijom kategorijom nereligioznih, dok je zanemariv udio onih koji to čine često. Najveći dio neodlučnih prigodno $(60,6 \%)$, blagdanski participira, dok ih trećina potpuno apstinira. Kategorija umjerenih vjernika također većinski participira prigodno (61,69\%), slijede oni koji to čine mjesečno i apstinenti. Povremeni praktikanti najveća su skupina u kategoriji uvjerenih vjernika $(33,3 \%)$, slijede prigodni pa tek onda redoviti praktikanti. Desetina ispitanika u toj kategoriji potpuni su apstinenti, što sugerira da je riječ o skupini koju karakterizira religijski identitet, ali ne i pripadanje vjerskoj zajednici. Dakle relativna redovitost (mjesečna i tjedna) obredne participacije natpolovično je prisutna samo u kategoriji uvjerenih vjernika.

Tablica 14.

Religijska samoidentifikacija i dominikalna praksa

\begin{tabular}{|l|c|c|c|c|}
\hline & NIKADA & $\begin{array}{c}\text { SAMO NA } \\
\text { VELIKE } \\
\text { BLAGDANE }\end{array}$ & $\begin{array}{c}\text { NEKOLIKO } \\
\text { PUTA } \\
\text { MJESEČNO }\end{array}$ & $\begin{array}{c}\text { BAREM } \\
\text { JEDNOM } \\
\text { TJEDNO }\end{array}$ \\
\hline UVJERENI/A ATEIST/ICA & 91,1 & 8,9 & 0,0 & 0,0 \\
\hline MNOGO SKLONIJI/JA NEVJEROVANJU NEGO VJEROVANJU & 57,7 & 40,5 & 0,9 & 0,9 \\
\hline NE ZNAM, NE MOGU PROCIJENITI & 32,9 & 60,6 & 5,3 & 1,2 \\
\hline MNOGO SKLONIJI/JA VJEROVANJU NEGO NEVJEROVANJU & 13,9 & 61,9 & 20,6 & 3,6 \\
\hline UVJEREN/A VJERNIK/CA & 10,4 & 28,9 & 33,3 & 27,4 \\
\hline
\end{tabular}

$=364,668 ; \mathrm{df}=12 ; \mathrm{C}=, 61 ; \mathrm{p}<, 001$ 
Jake statističke veze utvrđene su između religijske identifikacije i svih četiriju indikatora religijskog vjerovanja: postoji $\operatorname{Bog}(\mathrm{C}=, 71)$, Bog je stvorio svijet $(\mathrm{C}=, 62)$, postoje raj i pakao $(\mathrm{C}=, 62)$ i Bog je izvor moralnih principa $(\mathrm{C}=, 61)$, a u tablici 15. prikazane su dvije veze. Uvjereni su vjernici jedina kategorija koja natpolovično prihvaća sve četiri vjerske istine, a vjerovanje u postojanje Boga jest okosnica svrstavanja u kategoriju uvjerenih vjernika. U tu vjersku istinu vjeruju gotovo svi uvjereni vjernici, dok u preostalim trima dogmama nalazimo osipanje, jer ih prihvaća manje od tri četvrtine ispitanika iz ove kategorije. Četiri petine ispitanika sklonijih vjerovanju nego nevjerovanju također većinski vjeruju u postojanje Boga, ali istodobno i većinski sumnjaju u preostale tri tvrdnje. Rezultati govore u prilog tezi o disoluciji vjerovanja u onom dijelu uzorka koji se svrstava među vjernike, posebice umjerenijeg modaliteta. No očito vjerovanja selektiraju ne samo „umjereni“ vjernici već i oni koji sebe definiraju uvjerenim vjernicima. Sumnja u postojanje Boga karakteristika je najvećeg dijela neodlučnih ispitanika, ali i onih sklonijih nevjerovanju nego vjerovanju. Istodobno, dio neodlučnih ispitanika sklon je vjerovati u Božje postojanje, a nijedan nije sklon tu ideju odbaciti.

Tablica 15.

Religijska samoidentifikacija i vjerovanje u boga (u \%)

\begin{tabular}{|l|c|c|c|}
\hline & NE VJERUJEM & SUMNJAM & VJERUJEM \\
\hline & \multicolumn{3}{|c|}{ POSTOJI BOG } \\
\hline UVJERENI/A ATEIST/ICA & 83,3 & 15,6 & 1,1 \\
\hline MNOGO SKLONIJI/A NEVJEROVANJU NEGO VJEROVANJU & 27,0 & 55,0 & 18,0 \\
\hline NE ZNAM, NE MOGU PROCIJENITI & 0,0 & 73,7 & 26,3 \\
\hline MNOGO SKLONIJI/A VJEROVANJU NEGO NEVJEROVANJU & 0,0 & 17,7 & 82,3 \\
\hline UVJERENI/A VJERNIK/ICA & 0,7 & 0,7 & 98,5 \\
\hline & \multicolumn{2}{|c|}{ BOG JE STVORIO SVIJET } \\
\hline UVJERENI/A ATEIST/ICA & 97,8 & 2,2 & 0,0 \\
\hline MNOGO SKLONIJI/A NEVJEROVANJU NEGO VJEROVANJU & 59,5 & 36,0 & 4,5 \\
\hline NE ZNAM, NE MOGU PROCIJENITI & 31,6 & 58,9 & 9,5 \\
\hline MNOGO SKLONIJI/A VJEROVANJU NEGO NEVJEROVANJU & 13,5 & 51,0 & 35,4 \\
\hline UVJERENI/A VJERNIK/ICA & 4,5 & 23,1 & 72,4 \\
\hline
\end{tabular}

$\mathrm{p}<, 001$

U preostale tri tvrdnje neodlučni ispitanici većinski sumnjaju, a u većem postotku ne vjeruju nego vjeruju. Ispitanici skloniji nevjerovanju većinski odbacuju tri vjerske istine te u puno većem postotku sumnjaju nego vjeruju. Uvjereni su ateisti gotovo apsolutnu suglasnost uspostavili odbacivanjem tvrdnje o Božjem stvaranju svijeta, pa se može utvrditi da je to okosnica tog samosvrstavanja. Najveće raspršenje u toj skupini vezano je uz tvrdnju o postojanju Boga. U „nevjerničkom“ dijelu uzorka uvjereni ateisti iskazuju najveću konzistentnost identifikacije i vjerovanja. Udio onih koji tvrdnje odbacuju i sumnjaju u kategoriji sklonijih nevjerovanju podudaran je udjelu onih koji u njih sumnjaju i vjeruju u kategoriji onih sklonijih vjerovanju. 


\section{Zaključna razmatranja}

Sociološke analize institucionalne religioznosti kao dominantnog oblika religioznosti u hrvatskom društvu u proteklih četrdesetak godina nalaze s jedne strane blagi rast, ali i relativnu konstantnost u indikatorima tradicionalne religioznosti te s druge drastičan rast u indikatorima aktualne religioznosti u devedesetima. Tradicionalna je religioznost bila i ostala većinski proširena u hrvatskom društvu, dok je aktualna od marginalne pojave postala, u segmentima vjerovanja, identifikacije i prigodnog participiranja na misama, dijelom društvene normalnosti. Iako su mladi i u vrijeme socijalizma iskazivali većinsku tradicionalnu religioznost u nekolicini indikatora, ipak su u odnosu na druge dobne skupine bili najmanje i tradicionalno i aktualno vezani uz religiju i crkvu. Nova slika religioznosti mladih od devedesetih godina dvadesetog stoljeća nadalje uključuje daljnje širenje aktualne vezanosti, pa se mladi sve manje razlikuju od drugih dobnih skupina. Autori su na temelju podataka prikupljenih do 2010. godine zaključili da je na djelu stabilizacija religioznosti u hrvatskom društvu uopće (Črpić i Zrinščak, 2010.), pa tako i religioznosti mladih (Marinović Jerolimov i Jokić, 2010.). Međutim istraživanja provedena od 2010. godine na dalje na populaciji mladih (Ilišin i sur., 2013.; Ilišin i Spajić Vrkaš, 2015.) detektiraju nove promjene u religioznosti. Dolazi do značajnog pada u indikatorima aktualne vezanosti, participacije u obredima i religijskoj samoidentifikaciji, što nije dijagnosticirano u istraživanjima „odraslih“, pa se nameće zaključak da se mladi ponovno počinju značajno razlikovati od prosjeka populacije. Nacionalno istraživanje studentske populacije (Ilišin, 2014.) utvrdilo je da studenti u većini indikatora iskazuju slabiju, a u nekim indikatorima i znatno slabiju aktualnu religioznost od prosjeka populacije mladih.

Analiza rezultata istraživanja na uzorku riječkih studenata potvrdila je prvu hipotezu, da je tradicionalna religioznost dio društvene normalnosti obiteljskog ozračja u anketiranoj populaciji. Ogromna većina ispitanika u djetinjstvu je bila povezana s religijom i crkvom: inicirani su u vjersku zajednicu obredom krštenja, obiteljska je socijalizacija bila temperirana religijom, pohađali su školski vjeronauk te se natpolovični dio konfesionalno identificira. No veze između tih pokazatelja otkrivaju i indikativne otklone. Vjeronauk su pohađali i ispitanici koji nisu prošli obred inicijacije i koje roditelji nisu odgajali religiozno. Nadalje, pitanja o konfesionalnoj identifikaciji i pripadanju vjerskoj zajednici otkrila su da značajan dio anketiranih, usprkos iskustvu formalne i neformalne religijske socijalizacije, ne prepoznaje vlastitu konfesionalnost i tvrdi da nikada nije pripadao nijednoj vjerskoj zajednici, što govori o upitnosti sadržaja njihove veze s vjerskom zajednicom. Za objašnjenje te neočekivane pojave može se iskoristiti parafraza maksime iz Starkove teorije religijskog tržišta. U društvu gdje postoji monopol jedne religije pripadanje se dominantnoj vjerskoj zajednici podrazumijeva i „odrađuje po automatizmu“ te nerijetko ostaje nedomišljeno.

Kao i u svim prethodnim istraživanjima potvrđeno je da su indikatori aktualne vezanosti manje prošireni od indikatora tradicionalne vezanosti, čime je potvrđena i druga hipoteza istraživanja. Za razliku od Arnettovog istraživanja (2015.), svi su indikatori tradicionalne vezanosti statistički povezani s onima aktualne vezanosti, što ukazuje na značaj religijske socijalizacije za aktualnu vezanost uz religiju i crkvu. 
No nedosljednost između obiteljske (ne)religijske socijalizacije i aktualne (ne)religioznosti prisutna je u objema skupinama, onih koji jesu i onih koji nisu religijski socijalizirani. Obiteljska i formalna školska religijska socijalizacija imaju znatan utjecaj na kasniju identifikaciju, ali nisu jamstvo religioznosti u studentskoj dobi.

Vjerovanje u postojanje Boga najprošireniji je indikator aktualne religioznosti, kao i najprihvaćenija od četiriju ponuđenih vjerskih istina. No nevjera i sumnja u Božje postojanje karakteristika je gotovo polovine uzorka, pa vjerovanje u Boga nije opće mjesto svjetonazorske društvene normalnosti, barem kada je u pitanju studentski uzorak. Puno manje prihvaćanje ponuđenih religijskih istina od studenata u odnosu na prosjek populacije, kao i u odnosu na mlade u hrvatskom društvu, govori o slabijoj studentskoj religioznosti u domeni vjerovanja. Različita razina prihvaćanja pojedinih dogmi, većinska sumnja i nevjerovanje u tri od četiri ponuđene vjerske istine pokazatelj su disolucije vjerovanja.

Kada je riječ o religijskoj participaciji u misama, dominiraju blagdanski praktikanti, a slijede apstinenti, dok je redovitih praktikanata iznimno malo. Redovitije prisustvovanje misama neatraktivno je za većinu studenata, tako da najveći dio ostaje povezan s crkvom samo prigodno, blagdanski. Vidljivo je da se religioznost usvojena kroz obiteljsku religijsku socijalizaciju kasnije iskazuje u većini kao povremena, blagdanska obredna aktivnost ili kao (trenutni?) prekid veze s vjerskom zajednicom. Dakle obiteljska se religijska socijalizacija u vrlo maloj mjeri reproducira kao redovito religijsko ponašanje. Anketirani studenti natpolovično vjeruju u Boga i natpolovično se identificiraju vjernicima, ali sporadično slijede crkvene zahtjeve za dominikalnom praksom, što je simptom krize crkvene religioznosti, odnosno naznaka postojanja „pomaka od društveno-eklezijalne religioznosti prema subjektivnoj“ (Baloban i Črpić, 2000.:274-275).

Razlike u religioznosti povezane su i s sociodemografskim karakteristikama studenata, što govori u prilog trećoj hipotezi. Spol, obrazovanje majke, a u manjoj mjeri i oca, veličina naselja u kojima su odrasli i dio Hrvatske iz kojeg dolaze statistički su povezani s većinom indikatora religioznosti. Usprkos tome što te veze nisu pretjerano jake, one govore u prilog postojanju sekularizacijskih simptoma, koji su povezani s modernizacijskim promjenama u društvu i različitim regionalnim društvenim kontekstima u kojima se odvijala socijalizacija ispitanika. religioznosti manje religiozni od prosjeka mladih, koji su opet manje religiozni od prosjeka opće populacije.

Nakon iznimnog porasta crkvene religioznosti u devedesetima, koji je u velikoj mjeri bio obilježen i potaknut društvenim i političkim promjenama, izgleda da u drugom desetljeću ovog stoljeća dolazi do zaustavljanja tog procesa, i njegovog pada, barem kada je riječ o mladima. Kao da dividende koje je Crkva naplaćivala zbog suprotstavljanja komunizmu (Ferrari, 1995.) u mladim generacijama gube na vrijednosti. Mladi, a posebno studenti u okviru njih, opet su najmanje religiozna skupina u hrvatskom društvu u svim mjerenim indikatorima crkvenosti. Nekonzistentnost identifikacije, 
ponašanja i vjerovanja sugerira da je i dalje na djelu religija a la carté (Dobellaere), koja uključuje vrlo sporadične veze s crkvenom organizacijom. Stoga nije neutemeljeno o studentskoj religioznosti govoriti kao o „distanciranoj crkvenosti“ (Baloban i Črpić, 2000.), pa čak i o trendu „dekonfesionalizacije“ (Pickel, 2010.). Ostaje otvorenim pitanje hoće li se studenti koji su marginalizirali ili potpuno pasivizirali svoju vezu s religijom i crkvom u sljedećim etapama svog životnog puta (sklapanje braka i odgoj djece) tu vezu ponovno postaviti u svoje preferencije, kao što su to utvrdili Wilson i Sherkat (1994., prema Halliday Hardie, Pearce i Lundquist Denton, 2016.). Drugi mogući scenarij jest onaj koji također na uzorku mladih detektira Ozorak kada govori o adolescenciji kao razdoblju u kojem dolazi do procesa polarizacije, pa „jako religiozni postaju još religiozniji, dok ostali postaju manje religiozni“ (Ozorak, 1989., prema Halliday Hardie i sur, 2016.:153). Trend „profiliranja populacije na vjerničku i nevjerničku" na nacionalnom uzorku iz 2008. godine nalaze i hrvatski sociolozi Črpić i Zrinščak (2010.:21). Ukoliko je tome tako, onda slijedi da se to profiliranje zbiva i kao generacijski jaz, u kojem dolaze do izražaja sve veće generacijske razlike $\mathrm{u}$ institucionalnoj religioznosti.

Valja na kraju još jednom naglasiti i ograničenja ovog istraživanja zbog kojih treba biti oprezan pri generalizaciji njegovih rezultata. U uzorku prevladavaju ispitanici iz dviju hrvatskih regija koje su po razini modernizacije i sekularizacije znatno iznad hrvatskog prosjeka i u kojima je revival religioznosti bio manje entuzijastičan nego drugdje (Vrcan, 2001.; Jerolimov Marinović, 2002.; Boneta i Banovac, 2007.). Regionalne razlike u institucionalnoj religioznosti povezane su s etničkom i konfesionalnom strukturom sredine, iskustvima međuetničkih odnosa, koji se često percipiraju upravo kroz konfesionalne razlike. No usprkos tome nalazi istraživanja komparirani s prethodnim IDIS/Z-ovim istraživanjima upućuju na jasne trendove smanjenja crkvene religioznosti među mladima. Religioznost mladih i studenata nije stabilizirana, pitanje je može li se tako nešto uopće i očekivati u kontekstu suvremenog društva. Postojeća se nestabilnost može shvatiti kao njihanje klatna koje je u socijalizmu bilo na strani većinske nezainteresiranosti mladih za aktualne oblike crkvene religioznosti, da bi se devedesetih godina zanjihalo na suprotnu stranu, pa je došlo do drastičnog porasta religijske samoidentifikacije, prihvaćanja religijskih vjerovanja i religijske participacije. U drugom desetljeću ovog stoljeća, kao posljedica „nestabilne društvene dinamičnosti“ (Nikodem), klatno se opet vraća, što se očituje u opadanju u svim indikatorima institucionalne religioznosti među mladima i studentima.

\section{Literatura}

1. Ančić, B. i Puhovski, T. (2011). Vjera u obrazovanje i obrazovanje u vjeri. Stavovi i iskustva nereligioznih roditelja prema religiji i vjeronauku u javnim školama u Republici Hrvatskoj. Zagreb: Forum za slobodu odgoja.

2. Arnett, J. J. (2015). Emerging Adulthood. The Winding Road from the Late Teens Through the Twenties. Second Edition, Oxford: Oxford University Press.

3. Baloban, J. i Črpić, G. (2000). Određeni aspekti crkvenosti. Bogoslovska smotra, 70 (2): 257-290. 
4. Barth, F. (1997). Etničke grupe i njihove granice, U: Poutignat Philippe i StreiffFenart Jocelyne (Ur.). Teorije o etnicitetu. Zemun - Beograd: Biblioteka XX vek - Čigoja štampa, str. 211-279.

5. Berger, P. (2008). Desekularizacija sveta: opšti pregled, u Berger Peter L. (Ur.). Desekularizacija sveta. Oživljavanje religije i svetska politika. Novi Sad: Meditteran Publishing, str. 11-30.

6. Boneta, Ž. (2000). „Stabilizacija vjerničke strukture i/ili njihanje klatna - religioznost u Istri: prilog socio-religijskoj karti Hrvatske«. Revija za sociologiju, 31 (3-4): 133-152.

7. Boneta, Ž. (2007). Konfesionalnost i (dez)integracija višeetničkih područja. $M i$ gracijske i etničke teme, 23 (4): 409-422.

8. Boneta, Ž. i Banovac, B. (2007). Religioznost i nacionalizam na hrvatskoj periferiji - veliki scenariji za male zajednice. Migracijske i etničke teme, 23 (3): 163-184.

9. Bruce, S. (2011). Secularization. In Defence of an Unfashionable Theory. Oxford: Oxford University Press.

10. Cifrić, I. (1995). Vjernička struktura u tranzicijskom kontekstu hrvatskog društva. Društvena istraživanja, 4 (6): 819-836.

11. Črpić, G. i Zrinščak, S. (2010). Dinamičnost u stabilnosti: religioznost u Hrvatskoj 1999. i 2008. godine. Društvena istraživanja, 19 (105-106): 3-27.

12. Čulig, B.; Kufrin, K. i Landripet, I. (2007). EU + ? - Odnos građana Hrvatske prema pridruživanju Republike Hrvatske Europskoj uniji. Zagreb: FF press \& B.a.B.e.

13. Ferrari, S. (1995). Novo vino i stari mjehovi. Tolerancija, pravo i religija u suvremenoj Europi. Društvena istraživanja, 4 (20): 801-817.

14. Giordan, G. (2010). (Ur.). Annual Review of the Sociology of Religion. Volume 1: Youth and Religion. Leiden, Boston: Brill.

15. Goja, J. (2000). Neki aspekti religioznosti hrvatske mladeži 1986. i 1999. godine. Politička misao, 37 (1): 148-160.

16. Grce, M. (2016). Vjersko neznanje gorući problem. Novi list, rujan 2016.

17. Halliday Hardie, J.; Pearce, L. D. and Lundquist Denton, M. (2016). The Dynamics and Correlates of Religious Service Attendance in Adolescence. Youth $\varepsilon$ Society, 48 (2): 151-175. DOI 10.1177/0044118X13483777.

18. Ilišin, V. i Radin, F. (2002). (Ur.). Mladi uoči trećeg milenija. Zagreb: Institut za društvena istraživanja u Zagrebu i Državni zavod za zaštitu obitelji, materinstva i mladeži.

19. Ilišin, V. i Radin, F. (2007). (Ur.). Mladi: problem ili resurs. Zagreb: Institut za društvena istraživanja u Zagrebu.

20. Ilišin, V. i Spajić Vrkaš, V. (2015). Potrebe, problemi i potencijali mladih u Hrvatskoj. Istraživački izvještaj. Zagreb: Ministarstvo socijalne politike i mladih Zagreb.

21. Ilišin, V. (2014). (Ur.). Sociološki portret hrvatskih studenata. Zagreb: Institut za društvena istraživanja u Zagrebu.

22. Ilišin, V.; Bouillet, D.; Gvozdanović, A.; Potočnik, D. (2013). Mladi u vremenu krize. Zagreb: Institut za društvena istraživanja u Zagrebu, Friedrich Ebert Stiftung.

23. Marinović, D. (1988). Mladi i religija, U: Nenad Fanuko i sur. (Ur.). Fragmenti omladine. Zagreb: RK SSOH i IDIS, str: 183-198. 
24. Marinović Jerolimov, D. (1993). Religioznost, nereligioznost i neke vrijednosti mladih, U: Bahtijarević Štefica (Ur.). Prilozi izučavanju nereligioznosti $i$ ateizma 2. Zagreb: IDIS, str. 87-136.

25. Marinović Jerolimov, D. (2002). Nereligioznost u Hrvatskoj 1968-1990, U: Ilišin, V. i Radin, F. (Ur.). Mladi uoči trećeg milenija. Zagreb: IDIZ i Državni zavod za zaštitu obitelji, materinstva i mladeži, str. 79-124.

26. Marinović Jerolimov, D. i Jokić, B. (2010). Religion and Youth in Croatia, in: Giordan Giuseppe (Ed.). Annual Review of the Sociology of Religion. Volume 1: Youth and Religion. Leiden, Boston: Brill, p. 307-327.

27. Nikodem, K. (2011). Religija i crkva. Pitanja institucionalne religioznosti u suvremenom hrvatskom društvu. Socijalna ekologija, 20 (1): 5-30.

28. Nikodem, K. and Zrinščak, S. (2012). Croatia's Religious story; The Coexistence of Institutionalized and Individualized Religiosity, in: Pollack, D.; Müller, O. and Pickel, G. (Eds.). The Social Significance of Religion in the Enlarged Europe. Secularization, Individualization and Plurakization. Farnham, Burlinhton: Ashgate, p. 207-227.

29. Pickel, G. (2009). Secularization as a European Fate? - Results from the Church and Religion in an Enlarged Europe Project 2006, in: Pickel, G. and Müller, O. (Eds.). Church and Religion in Contemporary Europe. Results from Empirical and Comparative Research, 89-122.

30. Pickel, G. (2010). German Youth: Neither Participants nor Partakers in Religion?, in: Giordan, G. (Ed.). Annual Review of the Sociology of Religion. Volume 1: Youth and Religion Leiden, Boston: Brill, p. 251-287.

31. Potočnik, D. (2007). Socio-Economic Basis for Religious Socialization and Youth Issues in Croatia, in: Ott Michale R. (Ed.). The Future of Religion: Toward a Reconciled Society. Leiden, Boston: Brill, p. 365-383

32. Rimac, I. (2010). Komparativni pregled odgovora na pitanja u anketi Europskog istraživanja vrednota 1999. i 2008. Bogoslovska smotra, 80 (2): 425-525.

33. Šagi-Bunić, T. J. (1983). Katolička crkva i hrvatski narod. Zagreb: Kršćanska sadašnjost.

34. Šundalić, A. (1995). Konfesionalna pripadnost - religijsko ili političko obilježje. Društvena istraživanja, 4 (20): 911-926.

35. Voas, D.; McAndrew, S. and Storm, I. (2013). Modernization and the gender gap in religiosity: Evidence from cross-national European surveys. Köln Zeitschrift fur Soziologie und Socialpsychologie, 65 :259-283. DOI 10.1007/s11577-0130226-5.

36. Vrcan, S. (1980). Između ortodoksije i apostaze: vezanost ljudi za religiju i crkvu kod nas, U: Vušković, B. i Vrcan, S. (Ur.). Raspeto katoličanstvo. Zagreb: Naše teme, str. 273-343.

37. Vrcan, S. (2001). Vjera u vrtlozima tranzicije. Split: Glas Dalmacije - Revija Dalmatinske akcije. 


\title{
Željko Boneta
}

Faculty of Teacher Education in Rijeka, Rijeka, Croatia

e-mail:zboneta@uniri.hr

\section{The Pendulum is Still Swinging. Institutional Religiosity of Students in Rijeka}

\begin{abstract}
The article analyzes institutional religiosity of students in Rijeka. It questions the claim that the religiosity of young people in Croatia is stable and is becoming increasingly similar to the religiosity of "adults." The author's analysis relies on the available data from the national IDIZ (Institute for Social Research in Zagreb) research, and the research conducted in the first half of 2015 on a sample of eight components of the University of Rijeka ( $N=635$ ). National surveys conducted on young people in the last six years have indicated a stabilization of the actual religiosity in the dimension of religious beliefs. However, at the same time, religious self-identification and participation in religious ceremonies have been significantly declining. Young people, especially students within this age group, are by far the least religious category in the Croatian society.
\end{abstract}

Research conducted on a sample of students in Rijeka has shown a wide prevalence of traditional religiosity, yet lower in comparison to the results on the national scale. Adherence to religious practice is equally distributed throughout the sampled students in Rijeka, whereas indicators of religious beliefs and religious self-identification are significantly lower than the national average of their peers. Statistical analysis has shown that the socio-demographic characteristics of participants (gender, size of their hometown, parents' education and the region of Croatia they are from) are linked to the indicators of actual religiousness in accordance with the contextualized theory of secularization. Inconsistencies in identification, behaviour and belief among students point to a "distanced ecclesiality" which involves a very sporadic relationship between most respondents and the Church and for a non-negligible part of them this connection has been, at least temporarily, cut off. The current instability of institutionalized religiousness in young people and students can be explained by the swinging pendulum, which, after having reached the religiousness peak at the beginning of this century, is now going back to the center and, according to some indicators, even approaching the non-religious position. 